Makale Geliș | Received : 08.08.2019

Makale Kabul | Accepted : 26.10.2019

\title{
Salda Gölü ve Çevresinin Turizm Potansiyeli ve Yeşilova İlçesi’nin Sosyo-Ekonomik Yapısına Etkisi
}

\section{Tourism Potential of Salda Lake and Its Surroundings and Its Impact on Socio-Economic Structure of Yeşilova District}

\author{
Kadir TEMURÇIN ${ }^{*}$ \\ Yıldırım ATAYETER \\ Uğur TOZKOPARAN***
}

*Süleyman Demirel Üniversitesi Coğrafya Bölümü, kadirtemurcin@sdu.edu.tr

**Süleyman Demirel Üniversitesi Coğrafya Bölümü, yatayeter@sdu.edu.tr

***Mehmet Akif Ersoy Üniversitesi, Seyahat Turizm ve Eğlence Hizmetleri Bölümü, utozkoparan@mehmetakif.edu.tr

ORCID Numarası|ORCID Numbers: *0000-0002-8726-3756/**0000-0002-7570-2993/***0000-0002-3225-1651

Öz: Günümüzde, büyük şehirlerde yaşamanın birçok olumlu yanı bulunmasına rağmen şehirlerdeki yoğun nüfus artışı ile birlikte stres, trafik sorunları, hava kirliliği, gürültü kirliliği, doğal ortamların azlığı vb. gibi birçok sorun insanların yaşam kalitesini düşürmektedir. Bunun sonucunda insanların, yoğun şehir yaşamından uzaklaşarak doğayla iç içe olmalarını sağlayacak turizm aktivitelerine ilgisi artmıştır. Türkiye'de son yıllarda ciddi anlamda turist çeken doğa turizm kaynaklarından biri de ünü sınırlarımızın dışına taşan Burdur İli’nin Yeşilova İlçesi’nde yer alan Salda Gölü'dür. Burdur İli'nin içinde yer aldığı Göller Yöresi, Türkiye 2023 turizm stratejisinde, "Göller Bölgesi Ekoturizm Gelişim Bölgesi” olarak belirlenerek bölgedeki göllere dikkat çekilmiştir. Göller Yöresi içinde yer alan Salda Gölü, bölgesel ve uluslararası düzeyde önemli bir doğa turizmi potansiyeli taşımaktadır. Göle geçmişten günümüze değin çok sayıda yerli ve yabancı turist peyzaj güzellikleri görmek, fotoğraf çekmek, su sporları yapmak, kuş gözlemciliği, yamaç paraşütü gibi farklı turizm aktivitelerini gerçekleştirmek amacıyla gelmektedir. Salda Gölü'nün ünü, son dönemlerde özellikle T.V. kanallarında, gezginlerin sosyal bloglarında ve basında yapılan tanıtımların da katkısıyla daha fazla artmıs, bunun bir sonucu olarak da göl çok önemli ziyaretçi kitlelerini ağırlamaya bașlamıștır. Ancak özellikle yaz aylarında bölgeye gelen turistlerin çok fazla sayıda olması nedeniyle konaklama, sosyal ortam ve günlük gereksinimlerine yönelik ihtiyaçlarını karșılayacakları altyapı ve üstyapı ile ilgili hizmetler yetersiz kalmaktadır. Tüm bu gelișmeler kușkusuz, Yeșilova İlçesi’nde sosyal, ekonomik ve cevresel faktörler açısından da olumlu olduğu kadar bir o kadarda da olumsuz değișimleri de ortaya koymaktadır. Bu nedenle bu araştırmada Salda Gölü merkezli, Yeşilova İlçesi'nin turizm potansiyeli ele alınıp, artan turizm faaliyetlerinin Yeşilova İlçesi'nin sosyo-ekonomik yapısına etkileri araştırılmıștır. Çalıșmanın amacı, Yeşilova İlçesi’nde yaşayan yerel halkın ve işletmecilerin görüşleri üzerinden Salda Gölü'nde gerçekleştirilen turizm aktivitelerinin Yeşilova İlçesi’nin sosyo-ekonomik yapısına etkisini tespit etmek ve Yeşilova İlçesi’ndeki turizm faaliyetlerinin sürdürülebilirliğini sağlamak için yapılması gerekenleri ortaya koymaktır.

Anahtar Kelimeler: Coğrafya, Doğa Turizmi, Salda Gölü, Turizmin Etkileri

Abstract: Today, although there are many positive aspects of living in big cities, many problems, such as stress, traffic, air pollution, noise, the lack of natural environments, along with the intense population growth in the cities reduce the quality of people's lives. As a result, people have become more interested in tourism activities that will allow them to intertwine with nature by moving away from intense city life. One of the important nature tourism resources attracting tourists in Turkey in recent years is Lake Salda, which is located in Yesilova District of Burdur Province and it has a reputation beyond our borders, too.Lakes Region, in which Burdur Province is located, has been determined as "Lakes Region Eco-tourism Development Area" and attention has been drawn to the lakes in the region in Turkey 2023 tourism strategy. Lake Salda, located in the Lakes Region, has a significant potential of nature tourism at regional and international level. From the past to the present day, many local and foreign tourists come to the lake to do many different tourism activities, such as seeing the landscape beauties, taking pictures, doing water sports, bird watching and paragliding. Lake Salda's reputation has increased more recently through the contribution of the advertising activities on TV channels, travellers' social blogs and the media. As a result of this, the lake has begun to welcome important masses of visitors.But infrastructure and superstructure services are insufficient to meet the accommodation, social environment and daily needs of the tourists who come to the region especially during the summer months. All these developments undoubtedly provide positive changes in terms of social, economic and environmental factors in Yeşilova District but also negative changes. For this reason, in this study, tourism potential of Yeșilova District based in Salda Lake was examined and the effects of increasing tourism activities on the socio-economic structure of Yeșilova District were investigated. The aim of this study is to determine the effects of tourism activities carried out in Lake Salda on the socio-economic structure of Yeşilova District and to determine the sustainability of tourism activities in Yeşilova District through the opinions of locals and merchants living in Yeşilova. 


\section{Giriş}

Turizm, günümüzde dünyadaki birçok iş kolu ile ilişki içinde hem yeni iş alanları yaratması hem de ülkelerin milli gelirlerine büyük katkılar sağlaması sebebiyle gelişmiş veya gelişmemiş ülkeler arasında önemli bir rekabet alanı haline gelmiştir. Bu nedenle, günümüzün değişen şartlarının etkisi ile turist tercihlerinin farklılaşmasını da göz önünde bulunduran ülkeler, turistlere yönelik birçok farklı turizm aktivitelerini yapabilecekleri farklı turistik destinasyonlar sunarak turistleri kendi ülkelerine çekmeye çalışmaktadırlar. Bu anlamda, Dünya Turizm Örgütü (WTO)'nun 2011 yılında yayınladığı rapora göre turist tercihleri sadece deniz, kum, güneş turizmine bağlı olmaktan ziyade, farklı turizm aktivitelerinin ön plana çıktığı kırsal turizm alanlarına yönelmeye başlamıştır (Orhan ve Karahan, 2010). Farklı turizm aktiviteleri arayışının bir sonucu olarak ortaya çıkan kırsal turizm, kalabalık ve birçok farklı değişkenin etkili olduğu, yoğun şehir yaşamından kaçmak isteyen turistler için yeni bir tercih fırsatı olurken kırsal bölgelerin ekonomisine önemli katkılar sunmaktadır.

Kırsal turizm, genel olarak ekonomik temelde tarımsal ve hayvansal faaliyetlerin yoğun olarak yapıldığ1, kültürel ve yerel değerlerin yaşatıldığı kırsal yörelerde gerçekleştirilen etkinlikler bütünü olarak tanımlanmaktadır (Akça, 2004). 19. yüzyılda İngiltere'de yoğun şehir yaşamından kaçmak isteyen insanların doğaya yönelmesi ile başlayan kırsal turizm, şehirlerde yaşayan insanların sosyoekonomik durumlarının iyileşmesi, hızlı kentleşme, çevre kirliliği gibi etkenlerle Avrupa'nın sanayileşmiş ülkelerinde yayılmaya başlamıştır (Halbway ve Taylor 2006; Uçar, Uçar, Kurnaz ve Kurnaz, 2012). Yoğun kent yaşamının ortaya çıkardığı birçok sorun, insanların dinlenme, eğlenme, günlük hayattan kaçma gibi gereksinimlerini karşılamak için yeni yerlere özlem duymalarına neden olmuştur (Ukav, 2014). Bu özlem; deniz, kum, güneş şeklinde bahsedilen kitle turizminden sıkılan, şehirlerin yoğun ortamından uzaklaşarak doğayla iç içe yaşamak isteyen, yeni ilginç yerleri görüp ve farklı kültürleri tanımak isteyen kişilerin kırsal turizme yönelmelerine sebep olmuştur (Güney ve Göller, 2016). Doğanay ve Zaman'a göre (2016) zaten her hangi bir sahaya yönelik turizm hareketlerinin esas nedenini de doğal, beşeri ve kültürel kaynaklar oluşturmaktadır. Günümüzde kırsal turizm kavramı; çiftlik turizmi, köy turizmi, yayla turizmi, tarımsal (agro) turizm, eko turizm, av turizmi, mağara turizmi, doğa turizmi gibi turizm türleri ile aynı anlamda kullanılmaktadır (Soykan, 2003; Haberal, 2015; Uçar vd., 2012; Güney ve Göller, 2016).

Dünya Turizm Örgütü (UNWTO)'ne göre “kırsal alanda yapılan tüm faaliyetleri kapsayan turizm türü’ kırsal turizmdir (Akt: Deveci, Türkmen ve Avcıkurt, 2013; Güney ve Göller, 2016). Kırsal turizm, içerisinde özellikle kırsal bölgelerde doğa ile iç içe ve yörenin kültürel özelliklerinin de tanınmasına olanak sağlayan farklı turizm türlerini barındırmaktadır. Kırsal turizmde, özellikle de doğal turizm aktivitelerini içeren, kayak, bisiklet turları, atlı doğa gezileri, macera, rafting, su sporları, kuş gözlemciliği, dağcılık, termal turizm, avcılık daha çok ön plana çıkarken (Soykan, 2006); aile otelleri, tarihi yapılar, tarihi konaklar ve kırsalda yer alan mimari yapılar, kırsal bölgelerde ve çiftliklerde yapılan kamplar (Şerefoğlu, 2009; Uçar vd., 2012) gibi turizm aktiviteleri de kırsal turizmin kapsamına girmektedir.

Kırsal turizmin gelişebilmesi için kırsal turizm faaliyetlerinin yapılacağı bölgelerin bazı özellikleri taşımaları gerekmektedir. Bu özellikler (Avcıkurt ve Köroğlu, 2008; Soykan, 2006; Güney ve Göller, 2016):

- Coğrafi konumun ve kuruluş yerinin uygunluğu,

- Bölgeye özgü gelenek-görenekler, klyafetler, yiyecekler, zanaat ve festivallerin olmas1,

- Bölgedeki ulaşım, konaklama, yiyecek-içecek gibi işletmelerin uluslararası standartlara uygunluğu,

- Bölgenin sahip olduğu biyolojik çeşitlilik ve kültürel miras,

- Bölgedeki peyzajın çekiciliği. 


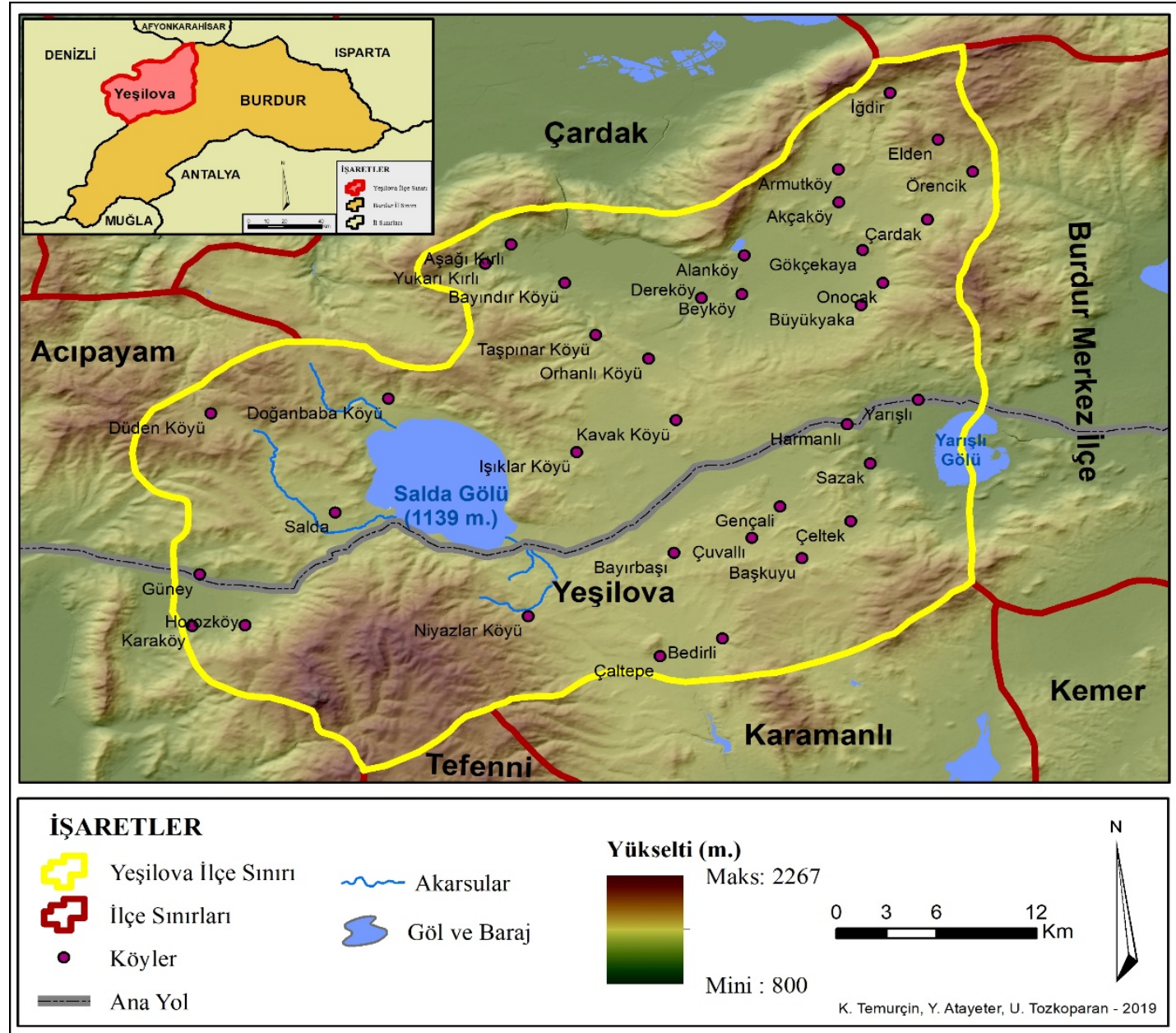

Şekil 1: Çalışma Sahasının Lokasyonu ve Topografik Görünümü

Akdeniz Bölgesi'nde turizm merkezlerine yakın bir konumda yer alan Burdur İli de turistlerin bu değișen tercihlerini gerçekleştirebilecekleri kırsal turizm kaynaklarına sahip illerimizin başında gelmektedir. Burdur İli’nde Merkez İlçe ile birlikte toplam 11 ilçe bulunmaktadır. Bu ilçelerden biri de araştırma sahasını oluşturan, Türkiye'nin en derin göllerinden biri olarak bilinen Salda Gölü'nün de içinde yer aldığ 1 Yeşilova İlçesi'dir (Şekil: 1). Yeşilova İlçesi $1351 \mathrm{~km}^{2}$ yüzölçümüne, 1200 metre ortalama rakıma ve 36 köye sahiptir. İlçe, Burdur il Merkezi'ne 60 km, Denizli İl Merkezi'ne $94 \mathrm{~km}$ ve Antalya İl Merkezi’ne $160 \mathrm{~km}$ uzaklıktadır. Burdur İli ve Yeşilova İlçesi, barındırdığı doğal, tarihi ve kültürel turizm değerleriyle Akdeniz Bölgesi'nden Ege Bölgesi ve ülkemizin iç bölgelerine geçiş güzergâhında, Göller Yöresi adı verilen bölgede, Türkiye'nin önemli turistik merkezlerinin bulunduğu Denizli-Antalya-Muğla illerine giden yollar üzerinde konumlanmış olmasının avantajıyla kırsal turizm faaliyetleri açısından büyük önem arz etmektedir.

$\mathrm{Bu}$ araştırmada, turizmin etkilerinden hareketle Yeşilova İlçesi'nin kırsal turizm potansiyeli ortaya konularak, son yıllarda Salda Gölü'nün etkisiyle Yeşilova İlçesi'ne gelen turist sayısının hızlı bir şekilde artmasının bir sonucu olarak ilçede gelişen kırsal turizm faaliyetlerinin ilçenin sosyo-ekonomik yapısına etkileri araştırılmıştır. Çalışmanın amacı doğrultusunda, Yeşilova İlçesi'nin turizm potansiyeli üzerinde durularak Yeşilova halkının ve işletmecilerinin ilçede son dönemde gelişen turizm faaliyetlerinin sosyo-ekonomik etkilerine yönelik düşünceleri araştırılmıştır. Ayrıca yapılan bu görüşmeler ile Yeşilova halkının ve yerel işletmecilerin kırsal turizm aktivitelerinin gerçekleştirilmesine yönelik ilçenin mevcut durumu, sorunları, çözüm önerileri üzerine görüşleri ele alınmıştır. Araştırmanın diğer bir amacı da ilçe halkının ve işletmecilerin görüşlerinden, ilgili literatür taramasından ve saha gözlemlerinden yola çıkarak ilçenin kırsal turizm anlamında mevcut potansiyelini, turizmle ilgili sorunlarını tespit etmek ve Yeşilova İlçesi'ndeki turizm faaliyetlerinin sürdürülebilirliğini sağlamak için yapılması gerekenleri ortaya koymaktır. 
Araștırmanın verileri, alan yazın taraması, saha ziyaretleri ve sosyal bilimlerin nitel araștırma yöntemlerinden yarı yapılandırılmış mülakat yöntemi ile elde edilmiştir. Araştırmada, derinlemesine veri elde etmek amacıyla açık uçlu soruların yer aldığı yarı-yapılandırılmış görüşme formu kullanılmıştır. Görüşme sorularının hazırlanması aşamasında ilgili alan yazından yararlanılmıştır. Görüşme yapılacak kişiler, işletmeler ve yerel halk arasından rastlantısal örnekleme yoluyla seçilmiştir. Görüşme yapılacak kişilere, görüşmeye başlanmadan önce araştırmanın amacından söz edilmiş araştırmaya katkı sunmak isteyenler ile görüşmeler gerçekleştirilmiştir.

\section{Yeşilova İlçesi’nin Kırsal Turizm Potansiyeli}

Kırsal bölgelerde turizmin gelişmesi ve sürdürülebilir olabilmesi için bazı şartların oluşması gereklidir. Bu koşullar: ulaşılabilirlik, yöreye özgü doğal güzellikler, tarihsel değerler, konaklama imkânları, yörenin kültürünü yansıtan geleneksel ürünler, su kaynakları ve rekreasyon etkinlikleri, bölge halkının turizme yönelik istekliliği, turizm faaliyetlerine katılmaya yatkınlığı, bölgenin gelişmeye açık olması ve bölgenin tüm değerlerinin korunmuş olması vb. gibi...(Soykan, 2004; Ongun, Gövdere ve Çiçek, 2016).

Yeşilova İlçesi, yukarıda ele alınan kırsal bölgelerde turizmin gelişebilmesi için gerekli temel şartlardan turistik kaynaklarla ilgili olan doğal, tarihi ve kültürel şartların çoğunu sağlamakta ve ulaşılabilir bir konumda yer almaktadır. Antalya ve Denizli-Pamukkale ana tur güzergâhı üzerinde yer alan Yeşilova İlçesi, önemli doğal ve tarihi sit alanlarına sahiptir. Yeşilova İlçesi ve çevre köylerinde daha önceki dönemlere tarihlenen camiler, kale surları, kale kalıntıları, türbe, ören yeri ve çok sayıda höyük bulunmaktadır. Tüm bu turistik değerler, doğal peyzaj güzellikleri yönünden zengin olan ilçenin tarih ve kültürel yönden de zenginliğine katkı sağlayarak kırsal turizm açısından ilçenin potansiyelini artırmaktadır (Şekil: 2).

Yeşilova İlçesi, Burdur İli'nin en eski yerleşim alanlarından biridir. İlçe sınırları içindeki Dereköy ve Gençali'de yapılan yüzey araştırmalarında Kalkolitik Döneme (M.Ö. 5000) ait ören yeri ve höyükler tespit edilmiş ve bu döneme tarihlenen çanak ve çömlekler bulunmuştur (Burdur İl Rehberi 2007; Atayeter, vd., 2013; Ongun, vd, 2016). Ayrica ilçe merkezine bağlı bir mahalle olan Kayadibi Mahallesi'nde, Geç Roma ve Erken Bizans dönemine tarihlenen ve Yarışlı Köyü'nde Asar olarak adlandırılan tepe üzerinde kale kalıntıları yer almaktadır (Kültür Envanteri, 2007a; Anonim, 2008; Ongun, vd., 2016). Bu eserlerin yanı sıra Türk-İslam dönemine ait Harmanlı Köyü'nde yer alan, kitabesinden 1207 yılında yapıldığı tespit edilen Harmanlı Camii, Horasan'dan gelerek Anadolu'nun Türkleşmesinde görev alan Selçuklu Beylerinden Niyazi Beyin yattığı Niyazi Baba Türbesi ve Onacak Köyü eski yerleşim alanı içerisinde 14. ve 15. yüzyıllarda yapıldığı rivayet edilen Onacak (Veli Dede) Türbesi ilçenin turizm potansiyeline değer katmaktadırlar (Erkan, 2008; Anonim, 2008; Kültür Envanteri, 2007a; Kültür Envanteri, 2017). 


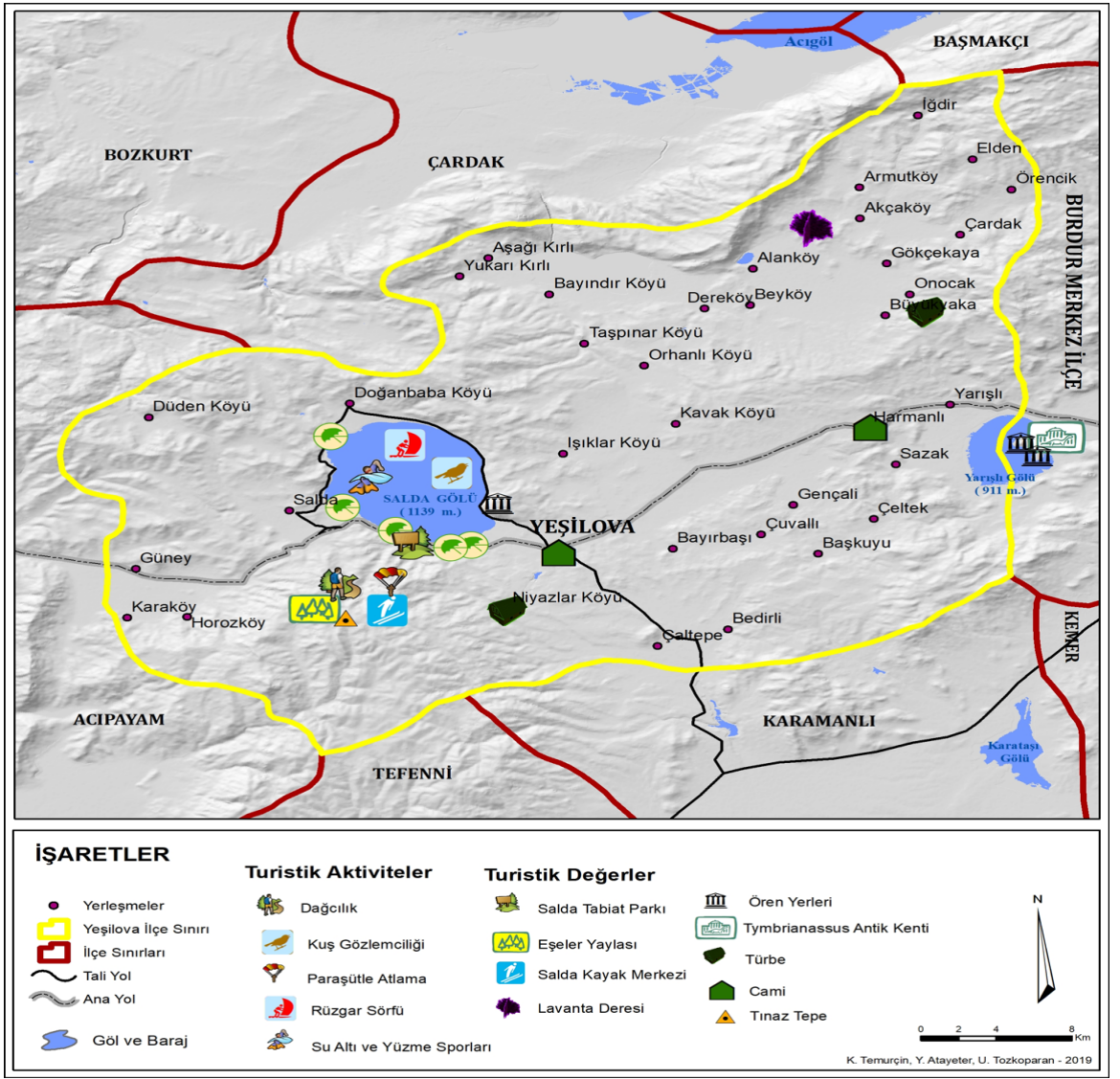

Şekil 2: Yeşilova İlçesi'nin Turistik Değerleri

Tarih ve kültür turizmi ile ilgili en eski devirlere ait eserleri ve ören yerlerini barındıran Yeşilova İlçesi, kırsal turizmde ilçeyi ön plana çıkaran ülke, bölge, il ve ilçe turizmine önemli katkılar sağlayacak birçok doğal turistik kaynağa da sahiptir. Bu doğal turistik değerlerden biri, Salda Gölü’ne karşı hâkim bir konumda yer alan, kış turizmi açısından önemli bir potansiyele sahip Tınaztepe mevkiinde, 2012 y1lında kurulmuş olan Salda Kayak Merkezidir (Ongun vd., 2016; Temurçin, 2014). Salda Kayak Merkezi, kış turizmi için önemli düzeyde potansiyele sahip olsa da belirli alt yapı eksiklikleri vardır. Başta ulaşım güzergâhının düzenlenmesi olmak üzere, kayak merkezinde konaklama tesisinin olmayışı en önemli problemler olarak görülmektedir. Salda Kayak Merkezi'ne yakın bir mesafede yer alan Eşeler Yaylası ilçenin en önemli yaylası olmakla beraber Salda Gölü ve Salda Kayak Merkezi’ni de içine alacak bir projeyle kırsal turizm potansiyeli açısından planlanabilecek önemli bir kırsal turizm kaynağıdır. Ancak ilçede faaliyet gösteren çok sayıdaki mermer ocağının doğada meydana getirdiği tahribat Yeşilova'nın yaylalarında düzenlenen turistik etkinlikleri olumsuz yönde etkilemektedir. Salda Gölü ve Burdur Gölü arasındaki havzada oluşmuş olan Yarışlı Gölü’de Yeşilova İlçesi'nin sahip olduğu önemli bir doğa turizmi kaynağıdır. Yaklaşık 1200 ha. alanı kaplayan Yarışlı Gölü, başta flamingolar olmak üzere angıt, kaşık gaga, kızkuşu, boz ördek ve dikkuyruk gibi bazı kuş türlerine yaşam alanı sunmaktadır (Akova, 2013: Ongun, vd., 2016). Yüksek kuş çeşitliliğine ve zenginliğine sahip olan Yarışlı Gölü ve çevresinde, özellikle sonbahar aylarında başta kuş gözlemciliği ve fotoğrafçılık olmak üzere kırsal turizm faaliyetleri açısından önemli bir turistik değerdir (DKMP Yarışlı Gölü, 2013b; Atayeter, Tozkoparan, Yayla ve Sakar, 2018).

Son yıllarda özellikle turizm sezonunda yerli ve yabancı turistleri Yeşilova İlçesi'ne çeken ve ilçenin en önemli kırsal turizm potansiyelini oluşturan turistik değer ise Salda Gölü'dür. $45 \mathrm{~km}^{2}$ yüzölçümüne sahip olan Salda Gölü, yaklaşı 6,8 km eninde, 9,186 km uzunluğunda kapalı bir havza içerisinde oluşmuştur (DKMP 6. Bölge, 2013a; Kesici, 2018). Yeşilova İlçe Merkezi'ne 4 km. uzaklıkta, deniz seviyesinden 1139 m. yükseklikte oluşmuş olan Salda Gölü, Türkiye'nin en derin (184 metre) ve en temiz göllerindendir (Akkuş, 1986; Şenol, 2011; DKMP 6. Bölge, 2013a; Ongun vd., 2015; Atayeter vd., 
2018). Dairemsi bir görünüme sahip olan Salda Gölü'nü besleyen başlıca akarsular Salda, Çitlikli, Köpek, Değirmendere ve Zaferpınar'dır (Doğanay ve Zaman, 2016).

1989 yılında I. Derece Sit Alanı olarak belirlenen Salda Gölü; suyunun temizliği, doğal plajları ve kumsalları, doğal özelliğini koruyan fiziksel çevre olanakları, gölde yaşayan çeşitli canlı türleri, su sporlarına el verişliliği, göl kenarındaki mesire yerleri, kamp alanları, eşsiz manzarası ve daha birçok özelliği ile kırsal turizm açısından bölgenin en etkili turizm potansiyeline sahip turistik değeridir (Atayeter vd., 2018). Salda Gölünün, son yıllarda sosyal ağlarda, gezginlerin sosyal bloglarında tanıtımının artmasına ek olarak yaz ve kış aylarında tur şirketlerinin yoğun olarak kullandıkları AntalyaDenizli Pamukkale Ana-Tur yolunun geçtiği güzergâh üzerinde yer alması gibi nedenlerin etkisi ile son iki yılda ziyaretçi sayısı çok fazla artmıştır (Tablo: 1).

Tablo 1: Salda Gölü ve Salda Tabiat Parkı Ziyaretçi Sayıları (2018)

\begin{tabular}{|l|l|l|l|l|l|l|}
\hline $\begin{array}{c}\text { Beyaz Adalar } \\
\text { Araç Girişi } \\
\text { (Araç Başına 5 Kişi) }\end{array}$ & \multicolumn{2}{c|}{$\begin{array}{c}\text { Salda Tabiat Parkı } \\
\text { Ziyaretçi Sayısı }\end{array}$} & \multicolumn{2}{c|}{$\begin{array}{c}\text { Belediye ve Doğanbaba Plajları } \\
\text { (Tahmini) }\end{array}$} & Toplam \\
\hline \multicolumn{2}{|c|}{292.000} & \multicolumn{2}{|c|}{97.730} & \multicolumn{2}{|c|}{300.000} & 689.730 \\
\hline $\mathbf{2 0 1 3}$ & $\mathbf{2 0 1 4}$ & $\mathbf{2 0 1 5}$ & $\mathbf{2 0 1 6}$ & $\mathbf{2 0 1 7}$ & $\mathbf{2 0 1 8}$ & Toplam \\
\hline 6596 & 34829 & 20995 & 36979 & 67115 & 95955 & 262,469 \\
\hline
\end{tabular}

Kaynak: Doğa ve Milli Parklar 6. Bölge Müdürlüğü ve Burdur İl Turizm ve Kültür Müdürlüğü verilerinden üretilmiş̧ir.

İlçeye gelen turist sayısının artması turizmin gelişmesi açısından iyi olsa da, Yeşilova İlçesi’nin mevcut imkânları özellikle konaklama, ikram hizmetleri, sosyal ortamlar açısından gelen turistlerin ihtiyaçlarını karşılamada yetersiz kalmaktadır (Şekil 3). Göl çevresinde kurulmuş olan Sultan Pınarı, Sahil Mola, Belediye Halk Plaj1 ve Orman Plaj1 gibi dinlenme tesisleri başta olmak üzere İlçe Merkezi'nde ve Salda Gölü çevresinde yer alan köylerde bulunan mevcut işletmeler ilçeye gelen kalabalık kitlelerin yeme, içme, konaklama ve eğlence gibi temel ihtiyaçlarını karşılamada hem kapasite hem de hizmet kalitesi yönünden yetersiz kalmaktadır (Tablo 2). İlçedeki esnaf ve ticaret odasının resmi kayıtları ile saha araştırmalarından 2019 temmuz ayı itibari ile ilçede 16 apart ile bir otelin faaliyete geçtiği ve çeşitli alanlarda 47 yeni işletmenin açıldığı tespit edilmekle birlikte bölgeye gelen turistlerin ihtiyaçlarının karşılanmasında yetersizlik devam etmektedir (Tablo 3).

Tablo 2: Yeşilova İlçesinde Faaliyet Gösteren İşletmelerin Dağılışı

\begin{tabular}{|l|l|l|l|l|l|}
\hline Konaklama & Salda & Kayadibi & Doğanbaba & İlçe Merkezi & Toplam \\
\hline Apart-Pansiyon & 9 & 4 & & 3 & 16 \\
\hline Otel & 1 & 1 & & 3 & \\
\hline Ticaret & & & & & 5 \\
\hline Yiyecek-İçecek & 2 & 1 & 1 & 27 & 31 \\
\hline Turistik Tesis & 2 & 2 & & & 4 \\
\hline Diğer & 2 & 3 & & 27 & 32 \\
\hline & $\mathbf{1 6}$ & $\mathbf{1 1}$ & $\mathbf{1}$ & $\mathbf{6 0}$ & $\mathbf{8 8}$ \\
\hline
\end{tabular}

Kaynak: Yeşilova Esnaf Odası ve araştırma sahasında yapılan arazi çalışmalarından elde edilmiştir. 


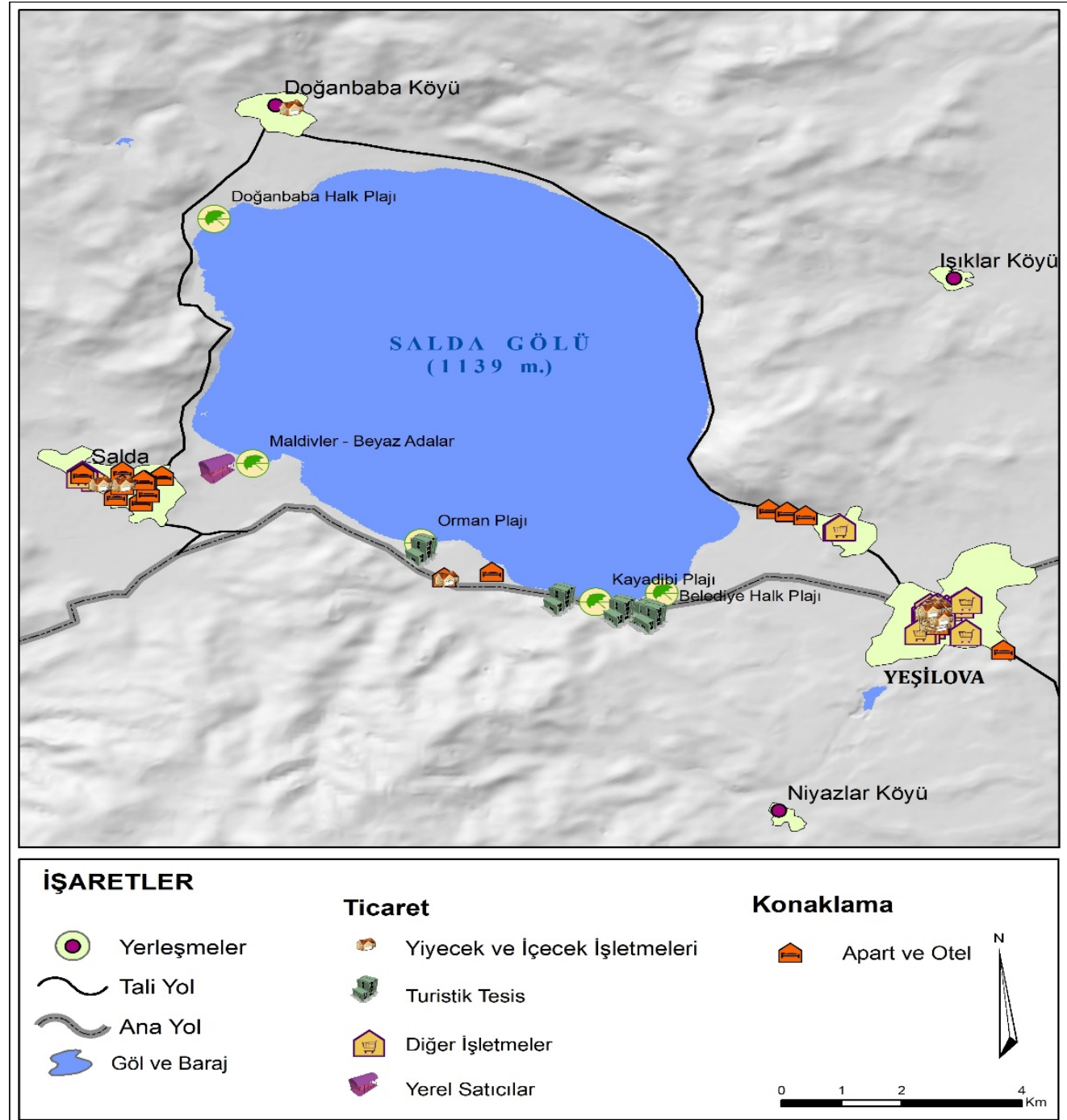

Şekil 3: Yeşilova İlçesinde Yer Alan İşletmelerin Dağılımı (Temmuz 2019)

Yeşilova İlçesi’nde, özellikle Salda Gölü çevresinde yer alan Salda Köyü, Doğan Baba Köyü ve Kayadibi Mahallesi başta olmak üzere birçok köy birer kırsal turizm değeridir. Bu köyler ve mahalleler hem Salda Gölü etrafinda konumlanmış olmaları hem de kültürel değerleri, yöresel dokumaları, yöresel yiyecekleri ile kırsal turizm açısından dikkat çekmektedirler. Bu açıdan bölgenin turizm planlamasında bu köylerin Salda Gölü etrafında yer aldıkları da dikkate alınarak doğal, tarihi ve kültürel değerleri ile kırsal turizm faaliyetleri kapsamında ele alınmaları bölgenin turizmi açısından son derece önem arz etmektedir. Bu köylerde doğal ortamın dokusuna uygun olarak inșa edilecek olan konaklama yerleri sayesinde hem turistlerin konaklama sorunu çözülecek, hem turistler yerel halk ile daha çok iletişim kuracak, hem de göl üzerindeki yoğunluk civardaki kırsal alanlara çekilecektir. Yapılan saha araştırmalarında gölün etrafında yer alan özellikle Salda Köyü ve Kayadibi Mahallesi'nde yerel halkın özellikle 2018-2019 yılları içinde evlerini apart-pansiyonlara dönüştürdükleri ve apart olarak kullanılmak üzere yeni yapıların yanı sıra lokanta, kafe ve bakkal gibi işletmeler açtıkları tespit edilmiştir (Tablo:3; Şekil: 3). 
Tablo 3: Yeşilova İlçesinde Yer Alan Otel-Apartların Oda Sayısı ve Kapasiteleri

\begin{tabular}{|c|c|c|c|c|}
\hline Otel ve Apart Adı & $\begin{array}{c}\text { Kuruluş } \\
\text { Yılı }\end{array}$ & Oda Sayısı & Yatak Kapasitesi & Bulunduğu Mevki \\
\hline Lagodi Salda Oteli & 2015 & 25 & 50 & Salda \\
\hline Salda Lake Otel & & 10 & 45 & $\begin{array}{l}\text { İlçe Merkezi } \\
\text { (Kayadibi Mahallesi) }\end{array}$ \\
\hline Otel Berliner & 1988 & 20 & 40 & İlçe Merkezi \\
\hline Görensel Otel & 1986 & 20 & 1986-2017:30, 2018: 45 & İlçe Merkezi \\
\hline Aromatik Otel & 2019 & 16 & 39 & İlçe Merkezi \\
\hline Turkuaz Apart & 2019 & 8 & 20 & İlçe Merkezi \\
\hline Sadıç Pansiyon & 2019 & 6 & 16 & İlçe Merkezi \\
\hline Sarmaşık Pansiyon & 2019 & 8 & 24 & İlçe Merkezi \\
\hline Ayaz Apart & 2018 & 7 & 14 & Salda Köyü \\
\hline Şahan Apart & 2018 & 4 & 12 & Salda Köyü \\
\hline Argun Apart & 2018 & 5 & 15 & Salda Köyü \\
\hline Salda Gölü Apart & 2019 & 3 & 18 & Salda Köyü \\
\hline Y1ldırım Apart & 2019 & 4 & 16 & Salda Köyü \\
\hline Erdoğan Apart & 2019 & 6 & 18 & Salda Köyü \\
\hline Canbazoğlu Apart & 2018 & 4 & 10 & Salda Köyü \\
\hline Maldivler Apart & 2019 & 4 & 9 & Salda Köyü \\
\hline Afacan Apart & 2019 & 6 & 18 & Salda Köyü \\
\hline Tan Apart & 2018 & 6 & 12 & Kayadibi Mahallesi \\
\hline Deveci Apart & 2019 & 6 & 18 & Kayadibi Mahallesi \\
\hline Ece Apart & 2019 & 6 & 18 & Kayadibi Mahallesi \\
\hline Venüs Apart & 2014 & 8 & 36 & Kayadibi Mahallesi \\
\hline Toplam & & 182 & 493 & \\
\hline
\end{tabular}

Kaynak: Arazi çalışmalarından elde edilen verilerden hazırlanmıştır.

Diğer yandan günümüzde lavanta bahçelerinin turistler tarafından çok tercih edilmeleri ve lavantanın tarımsal üretim açısından ekonomik bir değer olarak ön plana çıkması nedeniyle Yeşilova'nın bazı köylerinde lavanta dikimine başlanmıştır. Lavanta bahçelerinin, son yıllarda turistlerin dikkatini çekmesi nedeniyle Yeşilova'nın Akçaköy Köyü'nde Lavanta Deresi Projesi hayata geçirilerek yerel halkın lavantadan sadece tarımsal bir ürün olarak değil, ayrıca kırsal turizm faaliyetleri kapsamında ekonomik kazanç elde ettikleri turistik bir ürün olarak değerlendirmeye başlamışlardır. Bu durum lavanta yetiştirilen sahalarda yer alan köylerin kırsal turizm kapsamında değerlendirilmesini artırarak 
hem köylerin doğal ve kültürel değerlerini koruyacak hem de ekonomik anlamda kazanç elde etmelerini sağlayacaktır.

\section{Araştırmanın Bulguları}

Turizmin, gelişmeye başladığı bölgenin mekânı, ekonomik ve sosyal yapısı üzerinde yapmış olduğu değişimler nedeniyle, olumlu ve olumsuz etkileri vardır. Turizmin çok sayıda olan bu etkileri başlıca üç ana grup altında toplanabilir: ekonomik etkiler; toplumsal-kültürel etkiler; çevresel-ekolojik etkiler (Avc1kurt, 2015; Özgüç, 2017).

Yeşilova İlçesi, özellikle son dönemlerde Salda Gölü’nün ulusal ve uluslararası alanda tanınmasıyla farklı yerleri keşfetmek ve doğa ile iç içe olmak isteyen turistlerin dikkatini çekmiştir. Bunun sonucu olarak ilçeye gelen turist sayısı son iki yılda oldukça artmış ve resmi rakamlara göre 2019 yılı haziran ayı itibariyle 398.439 kişiyi bulmuştur. Bu anlamda Yeşilova İlçesi Salda Gölü merkezli sahip olduğu kültürel ve doğal değerleri ile ülkemizin gelecekteki en tanınan turistik destinasyonlarından biri olma yolunda hızla ilerlemektedir. Araştırmada, işletmecilerin ve yerel halkın turizmin ilçede ekonomik ve sosyal anlamda meydana getirdiği olumlu değişimin bilincinde oldukları ancak diğer yandan da ilçede ciddi altyapı-üstyapı eksikliklerinin olduğunun farkında oldukları, ilçede işletmeciler ile yerel halkın kalkınmasına katkı sağlayacak ve ilçenin tüm değerlerini korumayı merkeze alan turizm planlamasının yapılmasının gerekli olduğu tespit edilmiştir. Genel olarak bu tespitlerden hareketle, halkın desteğini alacak en iyi planlamanın yapılması için ilçede faaliyet gösteren işletmeciler ile yerel halkın görüşleri tespit edilmeye çalışılmış ve bu görüşlerden yola çıkarak yapılması gerekenlerle ilgili öneriler ortaya konmuştur.

\section{1. İşletmeciler Ve Yerel Halka Ait Bulgular}

Turizm faaliyetleri yapıldıkları bölgelerde yaşayan yerel halkı birçok açıdan doğrudan etkilemektedir. $\mathrm{Bu}$ yüzden, bölgede yaşayan yerel halkın turizm faaliyetlerine bakışının tespit edilmesi bölgedeki turizm faaliyetlerinin gelişimi bakımından önem arz etmektedir (Tatoğlu, Erdal, Özgür ve Azakl1, 2002; Kuven ve Akan, 2005; Beban ve Ok, 2006; Henderson, 2007; Uçar, Çeken ve Ökten, 2010; Kervankıran ve Temurçin, 2013; Giritlioğlu ve Bulut 2015; Akyürek, Özdemir ve Çeken, 2018). Bölgede yaşayan halkın görüşleri dikkate alınarak hazırlanan turizm planları sürdürülebilir turizmin önemli bir aşamasını oluşturmaktadır (Ap ve Crompton, 1998; Sarıkaya, Teye ve Sönmez, 2002; Çavuş ve Tanrısevdi, 2003; Akova, 2006; Öztürk, Özer ve Çalışkan, 2015). Yerel halkın turizm programlarına dâhil edilmesinin en etkili yollarının başında yerel halkın turizme yönelik görüşlerinin tespit edilmesi gelmektedir (Ap, 1992; Jackson, 2008; Boğan ve Sarış̧k, 2016).

$\mathrm{Bu}$ nedenle bu bölümde, Salda Gölü özelinde turizm faaliyetlerinin ilçenin sosyo-ekonomik yapısına olumlu-olumsuz etkileri ile ilçenin turizm açısından mevcut durumunu tespit etmeye yönelik Yeşilova İlçe Merkezi'nde ve Salda Gölü çevresinde faaliyet gösteren 25 işletmeci ve Yeşilova İlçesi'nde ikamet eden 25 kişi ile yapılan görüşmelere ait bulgular ele alınmıştır. Yapılan görüşmelerde hem yerel halka hem de işletmecilere aynı sorular sorulmuş ve alınan cevaplar büyük oranda aynı doğrultuda olduğu için alınan yanıtlar birleştirilerek genel olarak değerlendirilmiştir. Değerlendirmelere ek olarak her soruya yerel halk ve işletmecilerin görüşme esnasında verdikleri yanıtlardan birer örnek cümle eklenmiştir.

\subsubsection{Demografik Bulgular}

Tablo 4'te görüşme gerçekleştirilen işletmecilere ait demografik bilgiler yer almaktadır. Buna göre katılımcıların 18'i erkek 7'si kadın; 17'si evli 8'i bekâr,16'sı lise, 6'sı ilkokul ve 3'ü üniversite mezunu, yaşları 24 ile 69 yaş arasında değişmektedir. Katılımcıların tamamı Yeşilova İlçesi'nde ikâmet eden ticari işletme sahiplerinden oluşmaktadır. Katılımcılardan 9'u Yeşilova'da direk turizm ile ilgili, geri kalan 16 işletmecide İlçe Merkezi ve Salda Gölü çevresinde faaliyet gösteren işletmecilerden oluşmaktadır. Aynı zamanda katılımcılar otel, apart, cafe, pastane, plaj, turistik tesis, yerel satıcı, market ve fotoğrafçı gibi turizm sektörü ile alakalı işletmeleri çalıştırmaktadırlar. 
Tablo 5 'te araştırmaya katılan yerel halka ait demografik bilgiler yer almaktadır. Katılımcıların 18'i erkek 7'si kadın; 17'si evli 8'i bekâr, 9'u ilkokul, 4'ü ortaokul, 4'ü lise, 2'si ön lisans, 5'i lisans 1'i yüksek lisans mezunudur. Katılımcıların yaşları 22 ile 70 yaş arasında değişmektedir. Katılımcıların meslekleri Belediye Başkanı, Esnaf ve Sanatkârlar Odası Başkanı, akademisyen, memur, güvenlik görevlisi, şoför, fotoğrafçı, aşçı, demirci, sarraf, ev hanımı ve çalışmayan (öğrenci-emekli) şeklinde dağılım göstermektedir.

Tablo 4: Görüşme Gerçekleştirilen İşletmecilerin Demografik Bilgileri (2019)

\begin{tabular}{|c|c|c|c|c|c|c|c|}
\hline Katılımeı & Cinsiyet & Yaş & Meslek & Ĕ̆itim & Medeni Hali & İşletme Türü & Kuruluş Yılı \\
\hline 1 & $\mathrm{E}$ & 42 & Otel İşletmecisi & Lisans & Bekâr & Otel & 2015 \\
\hline 2 & $\mathrm{~K}$ & 33 & Apart Sorumlusu & Lise & Evli & Apart & 2018 \\
\hline 3 & $\mathrm{~K}$ & 26 & Ev Hanımı & Lise & Evli & Pastane & 2019 \\
\hline 4 & $\mathrm{E}$ & 44 & Fotoğrafç1 & Lise & Evli & Fotoğrafç1 & 2011 \\
\hline 5 & $\mathrm{~K}$ & 49 & Terzi & İlkokul & Evli & Cafe & 2015 \\
\hline 6 & $\mathrm{E}$ & 36 & Serbest M. & İlkokul & Bekâr & Cafe & 1999 \\
\hline 7 & $\mathrm{E}$ & 36 & Emlakçı & Lise & Bekâr & Otel & 2018 \\
\hline 8 & $\mathrm{E}$ & 37 & Turizmci & Lise & Bekâr & Kayadibi Plajı İşletmecisi & 2018 \\
\hline 9 & $\mathrm{E}$ & 47 & İşletmeci & Lise & Bekâr & Salda Tabiat Park1 İșletmesi & 2005 \\
\hline 10 & $\mathrm{E}$ & 24 & Arkeolog & Lisans & Bekâr & Belediye Halk Plajı Tesisi & 1992 \\
\hline 11 & $\mathrm{E}$ & 40 & Lokantac1 & Lise & Evli & Lokantac1 & 1993 \\
\hline 12 & K & 46 & Esnaf & Lise & Evli & Dinlenme Tesisi & 2013 \\
\hline 13 & $\mathrm{E}$ & 50 & Fotoğrafç1 & Lise & Evli & Fotoğrafc1 & 1969 \\
\hline 14 & $\mathrm{~K}$ & 37 & Kasap & Lise & Evli & Kasap & 1998 \\
\hline 15 & $\mathrm{E}$ & 44 & Fotoğrafç1 & Lise & Evli & Reklam ve Fotoğrafçı & 2005 \\
\hline 16 & $\mathrm{~K}$ & 50 & Ev Hanımı & İlkokul & Evli & Lokantac1 & 2011 \\
\hline 17 & $\mathrm{E}$ & 50 & Ev Hanımı & Lise & Evli & Lokantacı & 2018 \\
\hline 18 & $\mathrm{E}$ & 25 & Ashç & Lise & Bekâr & Lokantac1 & 2017 \\
\hline 19 & $\mathrm{E}$ & 65 & Turizmci & Lise & Evli & Turistik Tesis & 1987 \\
\hline 20 & $\mathrm{E}$ & 34 & Gıda Teknikeri & Önlisans & Bekâr & Market & 2018 \\
\hline 21 & $\mathrm{~K}$ & 60 & Ev Hanımı & İlkokul & Dul & Lokantac1 & 2005 \\
\hline 22 & $\mathrm{E}$ & 60 & Emekli & Lise & Evli & Market & 2018 \\
\hline 23 & $\mathrm{E}$ & 69 & Otel İșletmecisi & İlkokul & Evli & Otel & 2005 \\
\hline 24 & $\mathrm{E}$ & 42 & Pastaneci & İlkokul & Evli & Pastane & 2012 \\
\hline 25 & $\mathrm{E}$ & 44 & Fotoğrafç1 & Lise & Evli & Cafe & 2017 \\
\hline
\end{tabular}

Kaynak: Araştırma bölgesinde yapılan arazi çalışmasında elde edilen verilerden oluşturulmuştur.

Tablo 5: Görüşme Gerçekleştirilen Yerel Halkın Demografik Bilgileri (2019)

\begin{tabular}{|l|l|l|l|l|l|}
\hline $\begin{array}{c}\text { Katılımcı } \\
\text { Sayısı }\end{array}$ & Cinsiyet & \multicolumn{1}{|c|}{ Yaş } & \multicolumn{1}{|c|}{ Meslek } & Eğitim Durumu & Medeni Durum \\
\hline 1. & E & 33 & Akademisyen & Yüksek Lisans & Evli \\
\hline 2. & E & 67 & Belediye Başkanı & Lisans & Evli \\
\hline 3. & K & 27 & Memur & Lisans & Evli \\
\hline 4. & E & 34 & Özel Güvenlik & Önlisans & Bekâr \\
\hline 5. & E & 39 & Otobüs Şoförü & Lise & Bekâr \\
\hline 6. & E & 70 & Fotoğrafc1 & Ortaokul & Evli \\
\hline 7. & E & 43 & İnşaatçı & İlkokul & Evli \\
\hline 8. & E & 64 & Emekli & Ortaokul & Evli \\
\hline
\end{tabular}




\begin{tabular}{|c|c|c|c|c|c|}
\hline 9. & $\mathrm{E}$ & 22 & Yok & Önlisans & Bekâr \\
\hline 10. & $\mathrm{E}$ & 40 & Aşç1 & Ortaokul & Bekâr \\
\hline 11. & $\mathrm{E}$ & 45 & Sarraf & İlkokul & Evli \\
\hline 12. & $\mathrm{E}$ & 55 & Demirci & İlkokul & Evli \\
\hline 13. & $\mathrm{E}$ & 50 & Şoför & İlkokul & Evli \\
\hline 14. & $E$ & 65 & İlahiyatçı & Lisans & Evli \\
\hline 15. & $\mathrm{~K}$ & 25 & Kütüphaneci & Lisans & Bekâr \\
\hline 16. & $\mathrm{~K}$ & 33 & Güvenlik Görevlisi & Lise & Evli \\
\hline 17. & $\mathrm{E}$ & 45 & Esnaf Odası Başkanı & Lise & Evli \\
\hline 18. & $\mathrm{E}$ & 24 & Aşç1 & Lise & Bekâr \\
\hline 19. & $\mathrm{~K}$ & 58 & Ev Hanımı & İlkokul & Bekâr \\
\hline 20. & $\mathrm{~K}$ & 33 & Öğretmen & Lisans & Evli \\
\hline 21. & $E$ & 69 & Terzi & İlkokul & Evli \\
\hline 22. & $\mathrm{E}$ & 45 & Demirci & Ortaokul & Evli \\
\hline 23. & $\mathrm{E}$ & 63 & Şoför & İlkokul & Evli \\
\hline 24. & $\mathrm{~K}$ & 55 & Ev Hanımı & İlkokul & Evli \\
\hline 25. & $\mathrm{~K}$ & 38 & Ev Hanımı & İlkokul & Evli \\
\hline
\end{tabular}

Kaynak: Araştırma sahasında yapılan arazi çalışmalarından elde edilmiştir.

\subsection{2. İşletmeciler Ve Yerel Halkın Turizmin Ekonomik Etkilerine Yönelik Görüşlerine Ait Bulgular}

Turizm nedeniyle yerli ve yabancı turistlerin gitmiş oldukları yerlerde yeme-içme, konaklama, oradaki çeşitli aktivitelere katılma, turistik yerlere ulaşma, günlük ihtiyaçlarını karşılama ve yöreye özgü el sanatları, yiyecekler gibi faaliyetler için yapacakları harcamalar kırsal bölgelerde yaşayanların gelirlerini artırarak; bölgede yaşayanların refah seviyelerini yükseltmekte böylece kırsal yörenin alım gücünü de artırarak yeni turistik yatırımların önünü açmaktadır (Soykan; 1999; Uçar vd., 2010; Kadanalı ve Yazgan, 2012). Kırsal turizmle beraber bölgede altyapı, sağlık ve eğitim gibi hizmetlerinde sayı ve kalitesinde önemli olumlu gelişmeler meydana gelmektedir (Akça, Esengün ve Sayılı, 2001; Uçar vd., 2012; Temurçin, Aldırmaz ve Kılıç, 2018). Salda Gölü merkezli gelişen turizm faaliyetleri, Yeşilova İlçesi'nde ekonomik anlamda olumlu ve olumsuz etkilere yol açmaktadır. Araştırmanın bu bölümünde, Yeşilova İlçe Merkezi’nde faaliyet gösteren işletmeciler ile yerel halkın turizmin ilçede meydana getirdiği ekonomik etkilere yönelik görüşleri ele alınmıştır.

Son yıllarda ilçeye gelen turist sayısının artmasının ilçede ki yatırımları ve yeni işletmelerin açılmasını nasıl etkilediğine yönelik soruya görüşmeye katılan işletmeciler ve yerel halkın büyük çoğunluğu ilçedeki yatırımların arttığı ve belli alanlarda yeni işletmelerin açıldığı yönünde yanıt vermiş̧lerdir. Hem yerel halk hem de işletmeciler, ilçede son iki yılda özellikle apart, kafe ve lokanta gibi işletmelerin sayısında artış olduğunu belirtmişler ve bu durum arazi çalışmalarında da tespit edilmiştir. Yapılan saha ziyaretlerinde Salda Gölü çevresinde yerel halk tarafından işletilen yiyecek içecek işletmelerinin, Salda Köyü ve Kayadibi Mahallesi’nde ise yeni apartların açıldığı görülmüştür. 
İşletmeci: "Esnaf ve Sanatkârlar Odası'na göre turizme yönelik yeme içme tesislerinde son 2 yılda 100'e yakın yeni kayıt olmuştur. Bu da Salda Gölü'nü ziyaret eden turist sayısının yerel işletmelere olan etkisini göstermektedir." (1. Katılımcı)

Yerel Halk: "Arttı. Şimdi ben bu işi esnaf odası verilerine göre konuşayım...Yeni işletmelerimizde açılmaya devam ediyor. 2018'in sonu 2019'un başı itibariyle ilçemizde Salda Köyü ve Kayadibi Mahallesi'nde 13 apartımız esnaf odamıza kayıt olarak faaliyete başladı. Bu yıl Toplam 43 işletme esnaf odamıza kayıt oldu..." (17. Katılımcı).

Salda Gölü'nü ziyaret eden turist sayısının hızlı bir şekilde artmasının ilçedeki iş olanaklarını, istihdamı ve gelir düzeyini nasıl etkilediğine yönelik görüşlerini tespit etmek amacıyla yöneltilen soruya işletmecilerin büyük çoğunluğu artan turist sayısının ilçedeki iş olanaklarını, istihdamı artırdığı ancak gelir düzeyini henüz çok fazla artırmadığı yönünde yanıt vermişlerdir. İşletmeciler, özellikle yaz aylarında turistlerin yoğun bir şekilde Salda Gölü'ne gelmeleriyle kışın çalıştırdıkları personelin iki üç katı kadar (özellikle lokanta, kafe ve park türü işletmeler) eleman çalıştırdıklarını, hatta yazın çalıştıracak eleman bulmakta zorlandıklarını belirtmişlerdir. Yerel halktan görüşmeye katılan kişiler istihdam olanaklarının daha çok göl çevresinde yoğunlaştığını ve halktan ziyade işletmecilerin gelirlerinin daha çok artı̆̆̆ını belirtmişlerdir.

İlçe Merkezi’nde faaliyet gösteren esnaflar ile yerel halktan görüşmeye katılan kişiler turistlerin günübirlik şekilde özellikle Salda Gölü’nü görmek amacıyla gelmesinden dolayı İlçe Merkezi'nden ziyade Salda Gölü etrafında kurulan işletmelerin daha çok gelir sağladıklarını belirterek turistlerin konaklama olanaklarının artırılarak turistlerin İlçe Merkezi'ne daha da çekilmelerini sağlayacak planlamaların yapılmasını talep etmektedirler. Bu kapsamda aşağıda bazı katılımcıların görüşlerine yer verilmiştir.

İşletmeci: "Kişilerin iş istihdamını arttırdı ancak bu belirli işletmeler için geçerli...Turistik alanlarda, lokanta, çay bahçesi ve pastane gibi alanlarda artış olmaktadır.” (10. Katılımcı)

Yerel Halk: “íş olanakları daha çok Salda Gölü çevresinde yer alan Salda Köyü’nde ve Kayadibi Mahallesi'nde arttı.Örnek veriyorum gölün kenarında 20-30 tane tostçu ve gözlemeci vardı bunların yanında beş kişi daha çalışsa 150-200 kişi eder." (13. Katılımcı)

Yeşilova İlçesi'nin altyapı ve üstyapı anlamında son yıllarda artan turist sayısının ihtiyaçlarını karşılama konusunda yeterlilik durumunu tespit etmeye yönelik soruya görüşmeye katılan işletmeciler ve yerel halkın tamamı alt yapı ve üst yapının yetersiz olduğu yönünde yanıt vermiştir. Katılımcıların, Salda Gölü ve çevresinin sit alanı olmasının da bunda etkili olduğunu düşündükleri tespit edilmiştir. Katılımcılar, gelen turistlerin ilçedeki altyapının yetersizliğinden dolayı çok şikâyetçi olduklarını özellikle göl kenarındaki WC'lerin, duş ve soyunma kabinlerinin, kaliteli yemek ve konaklama tesislerinin yetersizliğinden dert yandıklarını belirtmişlerdir. Görüşmeye katılan işletmeciler ve yerel halk, özellikle Yeşilova İlçe Merkezi ile Burdur İl Merkezi arasındaki Karayolunun son beş yıldır her yaz yol yapım çalışması nedeniyle trafiğe kapatılmasının turizmi olumsuz etkilediğine ve ilçedeki mevcut yolların trafiği kaldırmadığına dikkat çekmektedirler.

Yeşilova Belediyesi ile ilgili kamu kurumları ivedilikle Yeşilova İlçesi’nin çöp sorununa çözüm bulmalı, atık yağlara ve katı atıklara yönelik projeler oluşturup tesisleri hayata geçirmelidir. Bunun yanında da halk bilinçlendirilerek çöpler ayrıştııılmalıdır. Bu kapsamda aşağıda bazı katılımcıların görüşlerine yer verilmiştir.

İşletmeci: "Turist sayısının artması Yeşilova'nın birçok hizmet konusunda notunun tamamen dipte olduğunu ortaya çıkardl. Alt yapı kesinlikle yetersizdir. Gölün kenarında da yeterli alt yapı bulunmamaktadır...Tesisatımız 1912 den kalma ilçenin ilk kurulduğu yıllardan buyana. " (9. Katılımcı)

Yerel Halk: “En büyük sıkıntımız göl kenarında tuvaletlerin yetersiz olması ve yeterli hijyenik ortamın olmayışı. Şuana kadar bunları çözecek kapsamlı bir çalışma yapılmadı, sezon açıldı ama hiçbir gelişmede yok.” (15. Katılımcı). 
Salda Gölü'ne gelen turist sayısının artmasının ev ve arsaların satış fiyatları ile kira bedellerini ve ilçedeki işletmelerin satış fiyatlarını nasıl etkilediğine yönelik soruya 12 işletmeci fiyatların özellikle arsa ve evlerde iki katına çıktığını, 3 işletmeci fiyatlarda artış olmadığını, 15 işletmeci ise fiyatlarda doğal olarak bir artış olduğunu ifade ederken; yerel halktan görüşmeye katılanların büyük çoğunluğu arsa, ev, apart, otel ve market gibi turizm ile yakından alakalı işletmelerde fiyatların fazla artış gösterdiği şeklinde yanıt vermişlerdir. Bazı işletmeciler ve yerel halktan görüşmeye katılanlar ilçeye gelen turist sayısının artmasını firsata çevirerek çok fazla fiyat artışına giden işletmelerin olduğunu ifade ederek bu durumun uygun olmadığını belirtmişlerdir. Genel anlamda İlçe Merkezi'nden ziyade Salda Gölü etrafında fiyat artışının daha çok olduğu tespit edilmiştir. Bu tür sorunların önüne geçmek için ilçede yapılan denetimlerin sıklaştırılması ve özellikle turistlerin yoğun olarak faydalandığı hizmet alanlarının kalite, standart ve fiyatlarının kontrol edilmesi gerekmektedir. Bu kapsamda aşağıda bazı katılımcıların görüşlerine yer verilmiştir.

İşletmeci: “Çok fazla arttı. 1000 TL'den 4000 TL'den çıktı̆̆ını gördüm. Marketlerdeki fiyatları bile etkiledi. Bunu kendi çıkarına çeviren esnaflarımız var. "(11. Katılımcı)

Yerel Halk: "Artırdl. 30 milyonluk tarla 100 milyon oldu. 1 dönüm tarla 100-150 milyondan aşă̆ı değil. Kiralar iki katına çıktı. Kiralar 300 liraydı 600 lira oldu. Ben böyle bir şey istemem. "(12. Katılımcl)

Salda Gölü'ne Millet Bahçesi'nin yapılmasını destekleyip desteklemedikleri ile Millet Bahçesinin İlçe turizmini ve ekonomisini nasıl etkileyeceğine yönelik görüşlerini tespit etmek amacıyla sorulan soruya işletmeciler ve yerel halktan görüşme gerçekleştirilen kişiler benzer şekilde cevaplar vermişlerdir. Görüşme gerçekleştirilen yerel halk ve işletmecilerin bir kısmı daha önce Salda Gölü kenarında açılmış olan işletmelerin ve seyyar satış dükkânlarının kapatılmasından yola çıkarak Millet Bahçesi yapılınca Yeşilova İlçe esnafi ve yerel halkından ziyade dışardan gelen büyük işletmecilerin turizmden para kazanacaklarını ileri sürerek, Millet Bahçesi'nin açılmasına karşı çıktıklarını belirtmişlerdir. Görüşme gerçekleştirilenlerin işletmeci ve yerel halkın bir kısmı da, Millet Bahçesi'nin yapımıyla ilçedeki düzensizliğin ortadan kalkacağını, turistlerin ihtiyaçlarının karşılanacağını ve gölün daha iyi korunacağını düşündüklerinden Millet Bahçesi’nin yapımını desteklediklerini belirtmişlerdir. Millet Bahçesi'nin yapılmasını destekleyen yerel halk ve işletmeciler, burada ilçe esnafına işletebilecekleri dükkânlar verildiğinde Yeşilova esnafının kazanacağını, yerli halka istihdam olanağının doğacağını da belirtmişlerdir. Bazı işletmeciler ise yapılacak olan Millet Bahçesinin göl çevresinde yoğun betonlaşmaya yol açmadan inşa edilmesini ve burada Yeşilova esnafina öncelik verilmesini istemektedirler.

Yerel halk ve işletmecilerin bir kısmı da Millet Bahçesi projesinin tam olarak içeriğini bilmedikleri için bir şey diyemeyeceklerini belirtmişlerdir. Bu kapsamda aşağıda bazı katılımcıların görüşlerine yer verilmiştir.

İşletmeci: "Ekonomik anlamda gelişebilir, gölün etrafi daha düzenli ve daha temiz olabilir. Gölün korunmasını sağlar. Ancak böyle bir şey de yapılır ise talep artacak ve gölün bozulmasına da neden olacaktır. Betonlaşma olur ve gölün yapısı bozulabilir. İlçe ekonomisini olumsuz etkileyebilir gölün kenarına işletmeler açılır ise haliyle oradan alışveriş yapacaklardır." (4. Katılımcı)

Yerel Halk: “Çok olumlu etkiler olur. Bugün Salda Gölü’nü besleyen su havzalarının da korunması gerekiyor. Etrafindaki havzalar korunmazsa gölün suyu gider. Millet Bahçesi yapılırsa devlet buraya her anlamda el atar, bazı pislikleri önler ve gölü korur. Halkta bunu istiyor. Ama halkın içinde istemeyenlerde var." (14. Katılımcl)

Yeşilova İlçesi'nde turizm faaliyetlerinin çeşitlendirilmesi, geliştirilmesi ve sürdürülebilirliğin sağlanması için yapılması gerekenlere yönelik işletmecilerin ve yerel halkın görüşlerini tespit etmek için sorulan soruya görüşmeye katılan işletmeciler ve yerel halk benzer görüşler belirtmişlerdir. Görüşme gerçekleştirilenler, öncelikle ilçedeki kamu kurumları ve ilçede bulunan Meslek Yüksekokulunun ortak çalışmalar yürüterek halkı ve esnafı turizm faaliyetleri açısından bilinçlendirecek çalışmalar yapmaları gerektiğini ifade etmişlerdir. Hem yerel halktan hem de 
işletmecilerden görüşmeye katılanlar yapılması gereken en önemli işlerin başında yeni ve kaliteli konaklama yerlerinin yapılmasının ilçedeki turizm faaliyetlerinin geleceği açısından önemli olduğunu düşündükleri tespit edilmiştir.

Görüşmeye katılan işletmeciler ve yerel halk, İlçe Merkezi'ndeki mevcut yollar ile Salda Gölü'ne ve tüm turistik destinasyonlara giden yolların yazın meydana gelen trafik yoğunluğunu kaldırmadığından tüm yolların genişletilmesi ve Yeşilova Belediyesi’nin Salda Gölü’ne yapılacak toplu ulaşım konusunda çalışmalar yapmasının gerekli olduğunu düşünmektedirler.

Yapılan görüşmelerden ve saha ziyaretlerinden yola çıkarak, ilçeye gelen turistler için öncelikli olarak konaklama alanlarının ve düzenli park alanlarının inşa edilmesi, yeni WC'lerin ve duş alanlarının yapılmasının ivedilikle sağlanmasının gerekli olduğu tespit edilmiştir. Salda Gölü çevresinde denetimsiz bir şekilde açılan işletmelerin vergi ödemeden, ilçe merkezine göre çok yüksek fiyatlarda satış yaparak haksız kazanç elde etmelerinin işletmecilerde rahatsızlık yarattığı, usulsüz şekilde ticaret yapılmasının, düzensizliğin ve adaletsizliğin önüne geçilmesi için denetimlerin artırılmasının da gerekli olduğu tespit edilmiştir. Yaz aylarında yetersiz kalan market, lokanta, fırın vb. gibi öncelikli ihtiyaçlara yönelik işletmelerin kapasitelerinin, kalitelerinin artırılması ve ilçedeki fiyatların iyi denetlenmesinin sağlanması bölgedeki turizm faaliyetlerinin gelişimi açısından son derece önemlidir.

İşletmeciler ve yerel halktan görüşmeye katılanların geneli sadece Salda Gölü'ne yönelik gelişen turizm faaliyetlerinin yazın 3-4 ay kazançlarını artırdığını ancak yılın genelinde bunun devam etmediğini belirterek turistlerin Salda Gölü'nden İlçe Merkezi'ne doğru çekilmesi ve yılın 12 ayına yayılacak turizm planlamalarının gerektiğini ifade etmişlerdir.

İşletmeci: "3-4 ay göl bizi kalkındırıyor ancak yetersiz kallyor. Burada kayak merkezi devreye giriyor. Oraya da projeli bir şekilde bir şeyler yapulırsa göl ve kayak merkezi birbirlerini tamamlayan iki kol olabilir. Kış turizmi de açılsa doğayı bozmadan daha da muazzam olur. "(12. Katılımcı)

Yerel Halk: "Tuvalet yok, lavabo ve duşa kabin yok, oturup yemek yiyecek kaliteli düzgün lokanta yok. Bunların hepsi şuanda eksik." (6. Katılımcl)

\subsection{3. İsşletmeciler Ve Yerel Halkın Turizmin Sosyal-Kültürel Etkileri ile İlgili Görüşlerine Ait Bulgular}

Kırsal turizm kültürel öğeleri de kapsadığ için kültürel varlıklar daha fazla korunmaya başlanarak yerel halkın ve bölgeye gelen turistlerin yörenin kültürü ile daha fazla ilgilenmelerine neden olacağından külttürün yeniden canlanmasını sağlamaktadır (Özçatalbaş, 2006; Uygur ve Baykan 2007). Bunun doğal bir sonucu olarak kırsal turizm, yerel kültürel değerlerin ekonomik kazanç sağlamak amacıyla yeniden yapılmasına neden olur (Middleton ve Rebecca, 1988).

Kırsal turizm geliştiği bölgenin toplumu üzerinde sosyal etkilere de neden olmaktadır. Turistler kırsal bölgeye görüşlerini, yaşam biçimlerini ve kendi alışkanlıklarını da getirerek yerel halkla etkileşime girerler. Bu etkileşim sonucunda yerel halkın toplumsal yapısında olumlu veya olumsuz değişimler ortaya çıkabilmektedir. Turizmin, hoşgörü ortamı yaratması, kırsal alanların kentleşmesini hızlandırması, boş zamanların değerlendirilmesini sağlaması, temizlik bilinci oluşturması, yerel halkın tarihsel ve kültürel değerlerini sahiplenme bilincini artırması ve aile bağlarını güçlendirmesi gibi çok sayıda olumlu etkisinden söz edilebilir. Ancak turizmin bu olumlu sosyal ve kültürel etkilerinin yanında yabancı düşmanlığını, suç oranlarını artırması, kültürü ticari metaya dönüştürmesi, yörenin geleneksel değerlerini ortadan kaldırması, turistlerden edinilen olumsuz davranışların toplumda sergilenmeye başlanması gibi toplum üzerinde olumsuz etkileri de vardır (Ahişapoğlu, 2006; Kozak, Kozak ve Kozak, 2011; Kadanalı ve Yazgan, 2012; Avcıkurt, 2015; Köleoğlu, 2018). Bu manada Salda Gölü merkezli olarak olarak Yeşilova İlçesi'nde artan turist sayısı nedeniyle ilçede birtakım sosyal ve kültürel değişimler de meydana gelmektedir. Araştırmanın bu bölümünde, Yeşilova İlçe Merkezi'nde işletmecilik yapan iş sahipleri ile yerel halkın turizmin ilçede neden olduğu sosyal-kültürel etkilere ve halkın turistlere karş1 tutumuna yönelik görüşleri ele alınmıştır. 
Salda Gölü'ne gelen turistlerin ilçe halkının gelenek ve göreneklerine yaptıkları olumlu ve olumsuz etkileri ölçmeye yönelik soruya görüşmeye katılan işletmeciler ve yerel halkın tamamı turistler günübirlik olarak geldiklerinden fazla etkileşim olmadığı bu nedenle gelenek ve göreneklere olumsuz etkilerinin olmadığ yönünde yanıt vermişlerdir. Görüşmeye katılan bazı işletmeciler ve yerel halk, turistlerin çok fazla sayıda gelmesinden dolayı yerel halkın bilinçli hareket etmeye başladığını, ilçenin gençlerinin dünyaya bakış açısını olumlu yönde etkilediğini ve ilçedeki gazinoların kapanmasını sağladığını ifade etmişlerdir. Bazı işletmeciler ve yerel halktan kişiler ise, turistlerin ilçenin yöresel kültürünü tanıtma ve yaşatma açısından olumlu etki yaptığını düşündükleri tespit edilmiştir. $\mathrm{Bu}$ anlamda, ilçe halkının yöresel ve geleneksel ürünleri üreterek turistlere satmaya başlamaları hem geleneksel kültürel değerlerin korunmasına hem de yöre kültürünün tanınmasına olumlu etki yapmaktadır. Bu kapsamda aşağıda bazı katılımcıların görüşlerine yer verilmiştir.

İşletmeci: “Olumsuz etkisi yoktur. Bizim halkımız zaten misafirperver hoş görülü bir yapıya sahiptir." (14. Katılımcl)

Yerel Halk: "Gelenek ve görenekler de bozulma değil de turistlere açıldı̆̆ için daha çok ön plana çıkma ve korunma var. Turistler gelenek ve görenekleri yaşatmamıza katkı sağllyorlar. İlçe halkımız tarhanasını, yöresel ürünlerini hatta etnik klyafetlerini gelen turistlere satıyorlar. "(16. Katılımcl)

Salda Gölü'ne ve Yeşilova İlçesi'ne gelen turistlerin kendilerine karşı sergilediği herhangi bir olumsuz davranış ile karşılaşma durumları ve ilçeye gelen turistlerden rahatsızlık duyup duymadıklarına yönelik soruya işletmeciler ve yerel halkın tamamı turistlerin gelmelerinden rahatsızlık duymadıkları yönünde cevap vermişlerdir. İşletmecilerden İlçe Merkezi'nde faaliyet gösterenlerin hepsi turistlerin kendilerine karşı herhangi bir olumsuz tavır ve davranışta bulunmadıklarını ifade ederken turistlerin yoğun olarak uğradıkları Salda Gölü etrafindaki işletmecilerden bazıları, turistlerin olumsuz tavır ve davranışları ile karşılaş̧ıklarını ifade etmişlerdir. Salda Gölü etrafında faaliyet gösteren işletmeciler, hafta sonları (özellikle pazar günleri) yoğunluktan dolayı gelenleri ağırlayamadıklarını, bunun sonucunda tartışmaların yaşandığını belirtmişlerdir. Yerel halktan görüşmeye katılan bir kişinin haricindekiler turistlerden kendilerine karşı olumsuz bir tavır ve davranış sergileyen biriyle karşılaşmadıklarını belirtmişlerdir. Bu kapsamda aşağıda bazı katılımcıların görüşlerine yer verilmiştir.

İşletmeci: "Ufak tefek şeyler oluyor. Ancak genelde bir sorunumuz yok ancak gelen kişiler, lavabolardan, elektrik, duş alanı, ulaşım konusu gibi sorunlardan dolayı bizden şikâyetçiler. Yolumuz tek şerit tam sezon başlayacakken yolu kapatıyorlar bu da turizmi olumsuz etkiliyor." (18.Katılımcı)

Yerel Halk: "Illçeye gelen turistlerden rahatsızlık duymuyoruz ama onlardan şikâyet duyuyoruz. Alt yapı ve konaklamanın yetersizliğinden çoğu kişi şikâyetçi.” (18. Katılımcı)

Turist sayısındaki hızlı artışın ilçedeki günlük yaşamı nasıl etkilediğine yönelik soruya görüşmeye katılan işletmeciler ile yerel halkın büyük çoğunluğu, daha çok yaz aylarında Salda Gölü etrafı ve özellikle Yeşilova İlçe Merkezi'nde çok ciddi trafik yoğunluğunun meydana geldiği, trafik kazalarının olduğu, market, firın ve kasap gibi işletmelerde hem turistlerin hem de yerel halkın ihtiyaçlarının karşılanması noktasında yetersizliklerin oluştuğunu dile getirmişlerdir. İşletmeciler ve yerel halktan görüşmeye katılanlar ilçede hiçbir trafik ışığının olmadığını ancak yaşanan yoğunluktan dolayı oluşan kazaların ve düzensizliğin önüne geçebilmek için özellikle yaz aylarında trafik 1şıklarının devreye sokulmasının gerektiğini ifade etmektedirler. Katılımcılar, ilçeye gelen turist sayısının artmasının, son 3 yılda ilçede günlük yaşamı canlandırdığını belirtmişlerdir. Bu kapsamda aşağıda bazı katılımcıların görüşlerine yer verilmiştir.

İşletmeci: "İlçe merkezinde olumlu etkiliyor 3-5 sene önce hiçbir hareketlilik yoktu ancak şuanda bir hareketlilik mevcut. İlçede insan popülasyonu oluyor. Olumsuz etkisi ise, trafik yoğunluğu ve çevre kirliliği." (10. Katılımcl)

Yerel Halk: "Günlük yaşamda trafik özellikle çok sıkışmakta ve günlük ihtiyaçların karşılanmasını sağlayan ürünleri tedarik eden esnaf sayısının az olmasından dolayı ürünler erken 
tükenmektedir. Bundan dolayı diğer gelen müşteriler bu ürünlerle günlük ihtiyaçlarını karşılama noktasinda zorlanmaktadırlar. " (7. Katılımcl)

İlçedeki yerel halk ile işletmecilerin ilçeye gelen turistlere kaşı tutum ve davranışlarını tespit etmeye yönelik soruya işletmeciler ve yerel halkın büyük çoğunluğu, Yeşilova halkının eskiden beri misafirperver olduğunu bundan dolayı hem esnafların hem de yerel halkın ilçeye gelen turistlere karşı misafirperver ve ilgili davrandıklarını ifade etmişlerdir. Görüşmeye katılanlardan bazıları, herkesin ilçeye gelen turistlere yardımcı olmaya çalıştığını ancak çok sayıda turistin gelmesi neticesinde ilçede ki market, firın, kasap vb. gibi ticarethanelerin yetersiz kalmasından dolayı yerel halkın rahatsız olduğunu belirtmişlerdir. Bu kapsamda aşağıda bazı katılımcıların görüşlerine yer verilmiştir.

İşletmeci: "Yeşilova halkı misafirperverdir. Gelen misafirlerimizden birinden dinledim kasabın bir tanesinden etini almış ancak pişirmek için tel ızgarası yokmuş kasapta demiş ki kullan geri getirirsin. Halk turistten memnun turiste halktan memnun, ancak güzel bir planlama ile Yeşilova ileri gelen turist bölgelerinden biri olmaya hak kazanacaktır. "9. Katılımcl)

Yerel Halk: "Halkımız sevecendir turiste karşı olumsuz hareketlerde bulunmazlar." (2. Katılımcl)

Salda Gölü’nü gezmek amacıyla gelen turistlerin sosyal kültürel açıdan ilçeye olumlu ve olumsuz etkilerini tespit etmeye yönelik soruya görüşmeye katılan yerel halk ve işletmecilerin çoğunluğu olumlu yönde katkı yaptıkları şeklinde yanıt vermişlerdir. Turistlerin, ilçe halkının daha uygun bir dil kullanmalarına neden oldukları tespit edilmiştir. Katılımcılar, turistlerin ilçeye kültürel etkiden çok ekonomik anlamda etkileri olduğunu düşünmektedirler. $\mathrm{Bu}$ kapsamda aşağıda bazı katılımcıların görüşlerine yer verilmiştir.

İşletmeci: "Bence katkıları var doğayı seven insanlar geliyor gezdikleri yerlerdeki şeyleri görüp buraya geldiklerinde bize anlatıyorlar bizde işletmemize bir şeyler katmaya çalışıyoruz. Fikir aşılaması yapıyorlar bize." (10. Katılımcı)

Yerel Halk: "Gelen turistlerin sosyal kültürel konularda ilçeye zarar verdiğini düșünmüyorum. Turistler sosyal kültürel ve ekonomik açıdan fayda sağlamakta, esnafin ve devletin ilçeye yatırım sağlanmasında büyük etkileri oluyor." (3. Katılımcı)

Yeşilova İlçesi'nin turistik değerlerinden hangilerini bildiklerini tespit etmeye yönelik soruya işletmecilerin ve yerel halkın büyük çoğunluğu sadece Salda Gölü ve Salda Kayak Merkezi yanıtını vermişlerdir. İşletmecilerin ve yerel halkın bir kısmı Salda Gölü, Salda Kayak Merkezi’ne ek olarak Eşeler Yaylası'nı ve Lavanta Bahçelerini ilçenin turistik değerleri olarak bildiklerini ifade etmişlerdir. Buradan hareketle işletmeciler ve yerel halkın ilçenin diğer doğal ve kültürel kırsal turizm kaynaklarının tamamını bilmedikleri sonucu ortaya çıkmaktadır. Ayrıca işletmecilerin geneli, ilçede yer alan tarihi değerlerden hiç bahsetmemişlerdir. İşletmeciler, yöreye gelen turistler ile en sik iletişim kuran kesimlerin başında geldiklerinden işletmecilere gelen turistlere göl dışındaki turistik alanları da aktarabilmeleri açısından kurslar verilebilir. Bu kapsamda aşağıda bazı katılımcıların görüşlerine yer verilmiştir.

İşletmeci: "Yeşilova ilçesinde Niyazi Baba türbesi, lavanta bahçelerini, Fakir Baykurt evini, Tınaz Tepe ve kayak merkezini, doğal yaylalarını, trekking sporuna uygun dağlarını, turistik değerler olarak adlandırabiliriz." (23. Katılımcı)

Yerel Halk: "Aslında bizim ilçemiz turistik yerler açısından çok zengin. Fakat biz bu değerlerimizi tanıtamadık. Salda Gölü, Salda Kayak Merkezi ve Eşeler Yaylası en bilinen yerler olsa da ilçemiz de Onocak Köyü'nde yer alan Onocak Türbesi dünyanın ilk akıl hastanesidir. Fakat tanıtımı pek yapılamadığı için pek fazla bilinmiyor. Flamingoların kışladı̆̆ı Yarışlı Gölü ve Lavanta Bahçelerimiz var." (17. Katılimcl). 


\subsection{4. İş̧letmeciler Ve Yerel Halkın Turizmin Çevresel Etkileri ile İlgili Görüşlerine Ait Bulgular}

Kırsal alanlarda gelişen turizm faaliyetleri bozulmamış doğal ortam üzerine temellendirildiği için kırsal turizm faaliyetlerinin çevre üzerinde meydana getireceği olumlu ve olumsuz etkilerle karşılaşmak ta kaçınılmazdır. Kırsal turizmin iyi planlanmaması durumunda, doğal kaynakların aşırı kullanımı, doğal ve tarihi sitlerin, yöreye has kültürel değerlerin özelliklerinin bozulması gibi olumsuz sonuçlar ile karşılaşılmaktadır (Ross and Wall, 1999; Soykan 2003; Uçar vd, 2012; Boğan ve Sarışık, 2016). Kırsal turizm bölgelerinde, su kaynaklarında kirlenme, ormanlık alanların ve doğal bitki örtüsünün tahribi, doğal oluşumların bozulması, tarımsal alanların ve sit alanlarının tahribi, denetimsiz, plansız ve kontrolsüz yapılaşma, aşırı betonlaşma ve turizm tesislerinin seçiminde yapılan hatalar vb. şekilde ortaya çıan problemler bölge halkının karşılaştıkları çevresel sorunların başında gelmektedir (Soykan, 1999; Kervankıran ve Bulut 2015; Köleoğlu, 2018). Bütün bu olumsuzlukların önlenmesi için kırsal bölgeler turizme koruma ve sürdürülebilirlikleri sağlanacak şekilde planlanarak açılmalıdır. Yapılacak planlamaların başarıya ulaşması için bölgede yaşayan halkın bilinçlendirilmesi ve yerel halkın görüşlerinin alınarak sürece dahil edilmeleri önem arz etmektedir. Araştırmanın bu bölümünde, artan ziyaretçi sayısının Salda Gölü ve çevresini nasıl etkilediğine yönelik ilçede faaliyet gösteren işletmeciler ile yerel halkın görüşleri ele alınmıştır.

Salda Gölü'ne gelen turistlerin Salda Gölü ve yakın sahasında neden oldukları çevresel etkileri tespit etmeye yönelik soruya görüşmeye katılan işletmeciler ile yerel halkın tamamı altyapı yetersizliği ve insanların bilinçsiz hareket etmesi nedeni ile en büyük problemin atık çöp sorunu olduğu yanıtını vermişlerdir. İşletmeciler ve yerel halktan görüşmeye katılanlar bu durumun hem gelen turistlerden hem de ilçe halkından kaynaklandığını ve çöp konteynırlarının yetersiz olduğunu belirtmişlerdir. Görüşmeye katılan yerel halk ve işletmeciler turist sayısındaki artışın ilçede trafik yoğunluğuna bağlı olarak park alanlarının yetersiz kaldığını belirtmiş̧lerdir. Bu kapsamda aşağıda bazı katılımcıların görüşlerine yer verilmiştir.

İşletmeci: "Özellikle göl çevresinde bir kanalizasyon sisteminin olmamasl, yeterli tuvalet sayısının olmaması, çöp kutularının olmaması vb. nedenlerle maalesef gölün doğal dokusu tehlike altına girmektedir." (1. Katılımcl)

Yerel Halk: "En büyük sıkıntımız göl ve çevresinin aşırı kirlenmesi. Maalesef göl kenarında hiçbir arıtma tesisimiz yok. Halkımızdan ve gelen turistlerden çevre bilinci zaylf olanlar çöplerini bırakıp gidiyorlar göl kirleniyor." (17. Katılımcl)

\section{Sonuç ve Öneriler}

Araştırmada Teke Yöresi ve kültürünün önemli bir merkezi olan Burdur İli’ne bağlı Yeşilova İlçesi’nin kırsal turizme yönelik kaynakları ele alınmış olup, Yeşilova İlçesi’nin kırsal turizm açısından önemli bir potansiyele sahip olduğu tespit edilmiştir. Yeşilova İlçesi'nde kırsal yaşamı yansıtan yaşam biçimlerinin devam ettirilmesi, barındırdığı tarihi, kültürel ve doğal kaynakları kırsal turizm için gerekli olan ana şartları sağlamaktadır. İlçede yer alan Salda Gölü, son yıllarda ülkemiz çapında haklı bir üne kavuşmuş ve ziyaretçi sayısı artmıştır. Öyle ki Salda Gölü, rekor denemeleri için Milli Sporcularımızı dahi bulunduğu bölgeye çekmiştir.

Yeşilova İlçesi'nde yer alan Salda Gölü'nün, son yıllarda çok sayıda turist tarafindan ziyaret edilmesinin bir sonucu olarak ilçede meydana gelen turizm faaliyetlerinin ilçenin ekonomik, sosyal-kültürel yapısına etkisini ve ilçedeki turizm faaliyetlerinin mevcut durumunu tespit etmek amacıyla gerçekleştirilen bu araştırmada ilçede faaliyet gösteren işletmecilerden ve yerel halktan 25 'er kişiyle görüşmeler gerçekleştirilmiştir. Görüşmeye katılan yerel halk ile işletmecilere aynı doğrultuda sorular sorulmuş ve alınan cevapların büyük oranda bir biri ile örtüştükleri görülmüştür. Görüşme gerçekleştirilen kişilerin görüşlerinden, Yeşilova halkının ve işletmecilerin ilçede gelişen turizm faaliyetlerinden memnun oldukları ve turizmin gelişmesini destekledikleri tespit edilmiştir.

Araştırma kapsamında, ilçede faaliyet gösteren işletmeciler ile yerel halkın turizmin ilçede meydana getirdiği ekonomik, sosyal, kültürel etkilere ve ilçedeki turizm faaliyetlerinin mevcut durumuna yönelik görüşlerinden elde edilen bulguları genel olarak değerlendirecek olursak;

Salda Gölü’ne gelen turist sayısının artmasının, ilçedeki işletmelerin sayısını, istihdamı ve iş olanaklarını artırdığı görülmüş̧ür. Yapılan saha araştırmaları ile ilçedeki esnaf ve ticaret odasının resmi 
kayıtlarından, ilçede daha önceki dönemlerde apart ve pansiyonculuk faaliyeti yapılmazken, 2018 y1lı ve 2019 başı itibari ile ilçe merkezinde 16 apart ile bir otelin faaliyete geçtiği ve çeşitli alanlarda 45 yeni işletmenin açıldığ 1 tespit edilmiştir. Bu anlamda ilçede daha çok konaklama ile yiyecek içecek hizmetlerine yönelik olan apart, lokanta, tostçu ve kafe tarzı işletmeler açılmıştır. Salda Gölü'ne gelen turist sayısına bağlı olarak Yeşilova İlçesi'nde gelir düzeyi artmış ancak bu artış özellikle göl çevresinde ve belli kesimlerde meydana gelmiştir. Yerel halk ve işletmecilerin artan gelirden her kesimin faydalanamamasından rahatsızlık duydukları görülmüştür. Ayrıca, Salda Gölü’ne gelen turist sayısının artmasının Salda Gölü çevresi ve Yeşilova İlçe Merkezi'ndeki arsa ve ev fiyatları ile kira bedellerini çok fazla yükselttiği ve halkın da bu durumdan rahatsız olduğu anlaşılmıştır.

Araştırmada, yerel halk ve işletmecilerin Yeşilova İlçesi'nin mevcut konaklama, yiyecek-içecek hizmetleri, eğlence hizmetleri ve ulaşım hizmetleri açısından standardı düşük ve yetersiz olduğunu düşündükleri anlaşılmıştır. Bu anlamda, arazi çalışmalarında özellikle turistlerin yoğun olarak ziyaret ettikleri Salda Gölü çevresinde yer alan lavabolar, tuvaletler, tesisler ve ulaşım hizmetlerinin ilçeye gelen turist sayısına göre sayı, kapasite ve kalite standartları açısından yetersiz oldukları tespit edilmiştir.

Araştırmada görüşmeye katılanların, artan turist sayısının ihtiyaçlarını karşılamak amacıyla Millet Bahçesinin yapılmasının olumlu olacağını düşündükleri ancak bazı konularda endişeli oldukları görülmüştür. Salda Gölü'ne Millet Bahçesi'nin yapılması kararı sonrasında, Salda Gölü ve çevresinin Cumhurbaşkanlığının 14/3/2019 Tarihli ve 824 Kararı ile Özel Çevre Koruma Bölgesi olarak ilan edilmesi nedeniyle göl kenarında ki belediye tesisleri de dâhil olmak üzere yerel halka ait tüm işletmelerin (çadır kampları, tostçu, gözlemeci, büfe vb.) kaldırılmasının halkta bir rahatsızlık yarattı̆̆ 1 tespit edilmiştir. Görüşme gerçekleştirilen katılımcıların bazıları, Millet Bahçesi yapıldıktan sonra ilçe esnafı ile yerel halktan çok dışardan gelen büyük yatırımcıların para kazanacaklarını düşündükleri bu nedenle Millet Bahçesinin yapılmasına karşı çıktıkları görülmüştür. Bazı katılımcılar ise, Millet Bahçesi'nin yapılmasının göl ve çevresinde betonlaşmaya neden olacağını ve doğal ortamın bozulacağını düşündüklerini bu nedenle yapılmasına karşı olduklarını belirtmişlerdir. Araştırmaya katılan işletmeci ve yerel halkın bir kısmı da, gelen turistlerin ihtiyaçlarının daha iyi karşılanacağı, gölün daha iyi korunacağı, ilçedeki halka iş imkânı sağlayacağı gibi nedenlerden dolayı Millet Bahçesi'nin yapılmasını destekledikleri gözlenmiştir.

Araştırmaya katılan yerel halk ve işletmeciler, gelen turist sayısının artmasının ilçenin gelenek ve göreneklerini olumsuz yönde etkilemediğini aksine turistlere satış yapmak maksadıyla yapılan üretimlerle birlikte geleneklerinin daha çok ön plana çıkmaya, hatırlanmaya ve korunmaya başlanmasına neden olduğunu düşündükleri tespit edilmiştir. İlçede özellikle yöresel ürünlerin üretilerek turistlere satılmaya başlanması bunların üretimini artırdığını ve unutulmalarını engellediğini ve turizmin gelenek ve göreneklere olumlu etkide bulunduğu tespit edilmiştir. Araştırmaya katılanların tamamının turistlerden rahatsızlık duymadıkları görülmüştür. Araştırmaya katılanların, yaz aylarında Salda Gölü'nü gezmek amacıyla ilçeye gelen turist sayısının artmasının ilçedeki günlük yaşamı canlandırdığını düşündükleri anlaşılmıştır. Ancak turistlerin çok fazla sayıda gelmesinin bir sonucu olarak günlük yaşamda, özellikle otel, lokanta, firın ve market gibi işletmelerin yetersiz kaldıklarını, ilçe halkının dahi firınlarda ekmek bulamadığını, İlçe Merkezi ve göl çevresindeki yolların yetersiz kaldığını ve trafik kazalarının ortaya çıktığını bu durumların ilçe halkının günlük yaşamını olumsuz etkilediğinden halkın bunlardan rahatsız olduğu belirlenmiştir.

Görüşme gerçekleştirilenlerin hepsinin Salda Gölü’ne gelen turist sayısının hızlı bir şekilde artmasının çevresel etkiler bakımından göl ve yakın çevresinin aşırı kirlenmesine, park sorununa ve çevre düzensizliğine neden olduğunu düşündükleri, bu durumdan endişe ettikleri anlaşılmıştır.

Yerel halk ve işletmecilerin Yeşilova İlçesi’nin turistik değerlerinden daha çok Salda Gölü, Salda Kayak Merkezi, Eşeler Yaylası'nı bildikleri tespit edilmiştir. Hem işletmecilerin hem de yerel halkın yakın çevrede yer alan turistik değerlere yönelik bilgi sahibi oldukları belirlenmiştir.

Araştırmada, Yeşilova İlçesi'nin turizm kaynaklarından en üst düzeyde faydalanabilmesi için altyapı ve tanıtım eksikliği başta olmak üzere birçok konuda çalışma yapılmasının gerekliliği ortaya çıkmıştır. Araştırma kapsamında yapılan değerlendirmeler ışı̆̆ında Burdur ili ve Yeşilova İlçe turizmine yönelik yapılması gerekenlere ilişkin önerilerimiz şu şekildedir: 
Son yıllarda hızlı bir şekilde artan turist sayısı ile birlikte Yeşilova ilçesinde ciddi anlamda konaklama sıkıntısı ortaya çıkmıştır. Çok kalabalık kitleleri ağırlayan ilçede turizm işletme belgeli sadece bir otel vardır. Otellerin sayısının, hizmet kalitelerinin ve özellikle turizm işletme belgeli otel sayısının artırılması sağlanmalıdır. Salda Gölü’ne gelen turist sayısının çok fazla olmasından dolayı kırsal turizm faaliyetlerine yönelik yapılacak çalışmalar kapsamında yerel halkın ev pansiyonculuğu yapmaya teşvik edilmesi konaklama problemlerinin çözümünde etkili olacaktır. Özellikle Salda Gölü etrafında yer alan Salda Köyü, Doğanbaba Köyü ve Kayadibi Mahallesi'nde yerel halkın açmaya başladığı apartların teşvik edilmesi konaklama probleminin çözümüne katkı sağlayacaktır. Bu kapsamda çevre köylerdeki yerel halka eğitimler verilerek bu civarlarda yeni yeni başlamış olan ev pansiyonculuğu ve apart yapımı teşvik edilmelidir. Bu anlamda, doğal çevreye uygun şekilde hostel, ağaç ev, bungalow, çadır vb. konaklama ünitelerinden oluşan komplekslerin ve su sporlarına yönelik bir merkezin açılması sağlanmalıdır.

Mevcut durum ve gelen turist sayısı dikkate alındığında önümüzdeki 10 yıl içinde Salda Gölü sadece Türkiye'nin değil dünyanın en önemli turistik destinasyonlarından biri olma potansiyeline sahiptir. Bu yüzden planlamalar sadece gölün plaj kısmı için değil gölün tüm kıyısı ile bütün olarak ele alınmalıdır. Göl ve çevresinde gelen turistlerin ihtiyaçlarını karşlayabilecekleri yapılaşma için acil planlamalar yapılmalıdır. Sadece göl kenarı değil göl çevresinde yer alan Salda Köyü, Doğanbaba Köyü ve Kayadibi Mahallesi'nde de bölgenin mimarisine uygun yatay yapılaşmaya gidilmelidir. Bu planlamalar da, göl çevresinin korunması ve sürdürülebilirliğin sağlanması göz önünde bulundurularak tesisleşme buna göre yapılmalıdır. Bu tesisler ciddi biçimde denetlenmeli ve uluslararası standartta olmalidir.

Var olan işletmelerin standartlarının artırılması, çalışanlara eğitim verilmesi sağlanmalıdır. Turizm sektörü ile ilgili işletmelerde istihdam edilecek elemanların yetiştirilmesi için Mehmet Akif Ersoy Üniversitesi bünyesinde bölümler açılarak ilgili kamu ve kurum kuruluşları ile ortak çalışmalar yürütülmelidir. Üniversite de alanında uzman akademisyenler tarafından mevcut çalışanlara sektörün taleplerini karşılayacak eğitimler verilmelidir.

Yeşilova İlçe Merkezi'nden Burdur İl Merkezi'ne giden karayolunun bir an önce tamamlanarak bu yolun özellikle turizm sezonunda trafiğge kapatılmasına son verilmelidir. İlçe genelinde karayolu ulaşım altyapısı iyileştirilmeli ve park sorununa çözüm üretilmelidir. Önemli turizm destinasyonlarına, ören yerlerine ve yaylalara ulaşımı sağlayan yollarda iyileştirme çalışmaları gerçekleştirilmeli yol güzergâhlarına tanıtıcı ve yönlendirici levhalar konulmalıdır.

Salda Kayak Merkezi, sadece kış aylarında kullanılmaktan çıkarılıp buranın Salda Gölü manzarasına sahip olmasından da hareket edilerek kayak merkezi, Eşeler Yaylası ve Salda Gölü ile beraber yapılacak kapsamlı bir planlama ile yayla şenlikleri, dağcılık, paraşütçülük, oryantiring, bisiklet ve kampçılık gibi alternatif turizm faaliyetleri açısından elverişli hale getirilerek 12 aya yayılacak şekilde kullanılması sağlanmalıdır. Bu amaçla, Triatlon, bisiklet, oryantiring federasyonları, kulüpleri ve dağcılık, trekking ve su altı dalış kulüpleri ile iletişime geçilmelidir. Burdur İli'nin Teke Yöresi'nin başkenti olarak anılması göz önünde bulundurularak Yeşilova İlçesi'nde yer alan Eşeler Yaylası'nda Salda Gölü ve Salda Kayak Merkezi'ni de içine alacak bir planlama ile yazın yayla şenliği kışın ise kış turizmi festivali yapılması planlanmalıdır. Yeşilova'da başta Salda Gölü, Salda Kayak Merkezi, Eşeler Yaylası ve Lavanta Deresi'nin önemli kırsal turizm kaynakları olarak bir bütün halinde ele alınmalarının ve bu kırsal turizm kaynaklarına yönelik tur planlarının düzenlenmesinin ilçenin kırsal turizm potansiyelinden daha çok faydalanılmasında olumlu sonuçlar sağlayacağı düşünülmektedir. $\mathrm{Bu}$ planlama ile ilçeye gelen turistlerin ilçede konaklamaları sağlanarak hem ilçenin turizmi geliştirilecek hem de daha fazla gelir sağlanacaktır. Salda Gölü ve çevresinin uluslararası kamp statüsü kazanması için izcilik federasyonu ile görüşülmelidir.

Valilik, kaymakamlık, belediyeler, ilde bulunan üniversite, ticaret ve sanayi odaları, sivil toplum kuruluşları başta olmak üzere il genelindeki kurum ve kuruluşların web sitelerinde etkili tanıtım faaliyetleri yürütülmelidir. Resmi ve ilgili kamu kurum ve kuruluşları tarafindan sürekli güncellenen Salda Gölü’ne gelecek olan turistlerin en güncel ve doğru bilgilere ulaşabilecekleri bir internet sitesi 
acilen devreye sokulmalıdır. Salda Gölü'nün ziyaretçi sayısı tespit edilerek bu site üzerinden Salda için konaklama vb. rezervasyonların yapılması ve böylece yoğunluğun önüne geçilmesi sağlanabilir. 


\section{Kaynakça}

Ahişapoğlu, S. ve Çeltek, E. (2006). Sürdürülebilir kırsal turizm, Ankara: Gazi Kitabevi.

Akça, H. (2004). Dünyada ve Türkiye'de Kırsal Turizm, Standart Dergisi, Eylül, 61-70.

Akça, H., Esengün, K. ve Sayılı, M. (2001). Kırsal Alanların Kalkındırılmasında Kırsal Turizmin Rolü, Standart Dergisi, 40(470): 29-35, Ankara.

Akkuş, A. (1986). Salda Gölünün Jeomorfolojisi, Ístanbul Üniversitesi Coğrafya Dergisi, Sayı: 2 , 109-115.

Akyürek, S., Özdemir, Ö. ve Çeken, H. (2018). Gümüşhane İlinin Kırsal Turizm Potansiyeli ve Yerel Halkın Kırsal Turizm Hakkındaki Görüşleri (Zigana Köyü Örneği), Uluslararası Kırsal Turizm ve Kalkınma Dergisi, 2 (2): s. 10-19.

Akova, O. (2006). "Yerel Halkın Turizmin Etkilerini Algılamalarına ve Tutumlarına Yönelik Bir Araştırma", Akademik Incelemeler Dergisi, 1(2).

Akova, A. (2013). Gökyüzünü Sevdiren Göller, National Geographic Traveller, Nisan, 44-52.

Anonim (2008). Gelişen Burdur, Burdur Ticaret ve Sanayi Odası (TSO) Yayınıdır.

Ap, John. (1992). Residents' Perceptions on Tourism Impacts, Annals of Tourism Research, 19(4), 665-690.

Ap, John., Crompton, John L. (1998). Developing and Testing a Tourism Impact Scale, Journal of Travel Research, 37(2), 120-130.

Atayeter, Y., Kanten, S. ve Kanten, P. (2013). Burdur Ili Turizm Potansiyelinin Değerlendirilmesi ve Rekabet Analizi, Fakülte Kitabevi: Isparta.

Atayeter, Y., Tokoparan, U., Yayla, O. ve Sakar, T. (2018). Coğrafi bir mekân olarak Burdur ilinin doğa turizmi potansiyelinin değerlendirilmesi. B. Eryılmaz, K. Özlü, Y.B. Kesin ve C. Yücetürk (Editörler), Sosyal Bilimlerde Güncel Akademik Çalışmalar 2018 (s. 683-719). Ankara: Gece Kitaplığ1.

Avcıkurt, C. ve Köroğlu, Ö. (2008). Kırsal Turizm. Necdet Hacıŏlu ve Cevdet Avcıkurt (Editörler).

Turistik Ürün Çeşitlendirmesi (s. 61-82). Ankara: Nobel Yayın Dağıtım.

Avcıkurt, C. (2015). Turizmin Sosyolojisi Genel ve Yapısal Yaklaşım, Detay Yayıncılık, Ankara.

Beban, A. ve Ok, H. (2006). "Contribution of Tourism to the Sustainable Development of the Local Community: The Case of Alanya and Dubrovnik”, Master's Programme in European Spatial Planning, Blekinge Institute of Technology.

Boğan, E. ve Sarışık, M. (2016). Yerel Halkın Turizm Faaliyetine Yönelik Görüş Ve Algılamalarının Belirlenmesi Üzerine Alanya'da Bir Araştırma. Kastamonu Üniversitesi Íktisadi ve İdari Bilimler $\begin{array}{llllll}\text { Fakültesi Dergisi, } & 12 & \text { (2), } & \text { 325-342. } & \text { Retrieved }\end{array}$ http://dergipark.org.tr/iibfdkastamonu/issue/29623/318110.

Burdur İl Kültür ve Turizm Müdürlüğü. (2007). Burdur İl Rehberi. T.C. Burdur Valiliği.

Burdur İl Kültür ve Turizm Müdürlüğü. (2007a). Kültür Envanteri Burdur Merkez. T.C. Burdur Valiliği.

Burdur İl Kültür ve Turizm Müdürlüğü. (2007b). Kültür Envanteri Burdur İlçeler. T.C. Burdur Valiliği.

Burdur İl Kültür ve Turizm Müdürlüğü. (2017). Kültür Envanteri Burdur Illçeler. T.C. Burdur Valiliği. 
Çavuş, Ş. ve Tanrısevdi, A. (2003). Residents' Attitudes Toward Tourism Development: A Case Study in Kuşadas1, Turkey, Tourism Analysis, 7(3-4), 259-269.

Deveci, B., Türkmen, S. ve Avcıkurt C. (2013). Kırsal Turizm ile Gastronomi Turizmi İlişkisi: Bigadiç Örneği, Uluslararası Sosyal ve Ekonomik Bilimler Dergisi, 3 (2), 29-34.

Doğanay, H. ve Zaman, S. (2016). Türkiye Turizm Coğrafyası, Pegem Akademi: Ankara.

Doğa Koruma ve Milli Parklar, (2013a). Salda Gölü, Doğa Koruma ve Milli Parklar 6. Bölge Müdürlüğü.

Doğa Koruma ve Milli Parklar, (2013b). Yarışlı Gölü, Doğa Koruma ve Milli Parklar 6. Bölge Müdürlüğü.

Erkan, Y. (2008). Zamanın Ötesinden Burdur Gezi Rehberi, Renk Matbaası: İstanbul.

Giritlioğlu, İ. ve Elmas, B. (2015). Yerel Halkın Bakış Açısına Göre Gaziantep Turizmi ve Sürdürülebilirlik, Uluslararası Sosyal ve Ekonomik Bilimler Dergisi, 5(1), 25-31.

Güney, D. ve Göller, V. (2016). Kırsal Turizm Konusunda Yerel Halkın Yaklaşımının Belirlenmesi: Misi Köyü Örneği, Turizm Akademik Dergisi, 3 (2), 25-36.

Haberal, H. (2015). Turizmde Alternatif- Doğa Turizmi - Kırsal Turizm - Yayla Turizmi. Ankara: Detay Yayıncılık.

Halbway, C., J. ve Taylor, N. (2006). The Business of Tourism Seventh Edition. England: Prentice Hall.

Henderson, Joan, C. (2007). Corporate Social Responsibility and Tourism: Hotel Companies in Phuket, Thailand, after the Indian Ocean Tsunami, International Journal of Hospitality Management, 26(1), 228-239.

Jackson, Leonard A. (2008). Residents' Perceptions of The Impacts of Special Event Tourism, Journal of Place Management and Development, 1(3), 240-255.

Kadanal1, E. ve Yazgan, Ş. (2012). Kırsal Turizmin Ekonomik-Sosyal ve Çevresel Etkileri, KMÜ Sosyal ve Ekonomik Araştırmalar Derg isi 14 (23): 97-100, 2012.

Kervankıran. İ. ve Temurçin, K. (2013). Afyonkarahisar ilinde ekoturizme yönelik yerel halkın yaklaşımları, Coğrafyacılar Derneği Yıllık Kongresi Bildiriler Kitabı, 19-21 Haziran 2013, Fatih Üniversitesi, İstanbul.

Kervankıran, İ. ve Bulut, E. (2015). Antalya İli Turizminin Gelişimini ve Etkilerini Yerel Halk Nasıl Değerlendirmektedir, Türk Coğrafya Dergisi, 65, 35-45.

Kesici, E. (2018). Salda Gölü Korunan Alanının Sürdürülebilirliği. Doğanın Sesi, (1), 3-11. Retrieved from http://dergipark.org.tr/dosder/issue/42353/509753.

Kozak, N., Kozak, M. A. ve Kozak, M. (2011). Genel Turizm, 11. Baskı, Detay Yayınc1lı, Ankara.

Köleoğlu, N. (2018). Turizmin Etkilerine Karşı Yerel Halkın Algılarının Değerlendirilmesi: Gelibolu Tarihi Alan Bölgesinde Bir Araştırma. Selçuk Üniversitesi İletişim Fakültesi Akademik Dergisi, 11 (2), 214-231. DOI: 10.18094/josc.409246.

Kuvan, Y. ve Akan, P. (2005). Residents' Attitudes toward General and Forest-Related Impacts of Tourism: The Case of Belek, Antalya, Tourism Management, 26(5), 691-706.

Middleton, V. T.C. ve Rebecca H. (1988). Sustainable Tourism; A Marketing Perspective, Butter WorthHeinemann Linance House. Oxford: Jordan Hill. 
Ongun, U., Gövdere, B. ve Kaygısız Durgun, A. (2015). Burdur İlinin Kırsal Turizm Potansiyelinin Değerlendirilmesi: Sorunları ve Çözüm Önerileri, Mehmet Akif Ersoy Üniversitesi Sosyal Bilimler Enstitüsü Dergisi, Cilt: 7, Sayı: 12, 99-116.

Ongun, U., Gövdere, B. Ve Çiçek, U. (2016). Yeşilova'nın kırsal turizm potansiyelinin swot analizi ile değerlendirilmesi. Süleyman Demirel Üniversitesi Vizyoner Dergisi, 7 (16), 75-88. DOI: 10.21076/vizyoner.265473.

Orhan, T. ve Karahan, F. (2010). Uzundere İlçesi ve Yakın Çevresinin Ekoturizm Potansiye-linin Değerlendirilmesi, Artvin Çoruh Üniversitesi Orman Fakültesi Dergisi, 11 (1), ss. 27-42.

Özçatalbaş, O. (2006). Türkiye'de Kırsal Turizm Potansiyeli ve Geliştirilmesi, Turizm ve Mimarlık Sempozyumu (28-29 Nisan), Bildiriler Kitab1, Antalya s: 272-278.

Özgüç, N. (2017). Turizm Coğrafyası Özellikler ve Bölgeler. İstanbul: Çantay Yayıncılık.

Öztürk, A. B., Özer, Ö. ve Çalışkan, U. (2015). The Relationship between Local Residents Perceptions of Tourism and Their Happiness: A Case of Kusadasi, Turkey, Tourism Review, 70(3), 232-242.

Ross, S. and Wall, G. (1999). Ecotourism: Towards Congruence Between Theory and Practice, Tourism Management, Vol:20, pp:123-132.

Sarıkaya, E., Teye, V. ve Sönmez, S. (2002). Understanding Residents' Support for Tourism Development in The Central Region of Ghana, Journal of Travel Research, 41(1), 57-67.

Soykan, F. (1999). Doğal Çevre ve Kırsal Kültürle Bütünleşen Bir Turizm Türü: Kırsal Turizm. Kırsal Turizm", Anatolia: Turizm Araştırmaları Dergisi, Yı1: 10-Mayıs-Haziran.

Soykan, F. (2003). Kırsal Turizm ve Türkiye İçin Önemi, Ege Coğrafya Dergisi, (12): 1-13.

Soykan, F. (2004). Bir Turizm Coğrafyası Araştırması: Kırsal Alanların Turizm Potansiyelinin Saptanması ve Şirince Köyüne (İzmir) Uygulaması, Ege Üniversitesi Basımevi, İzmir.

Şenol, F. (2011). Turizm Coğrafyası ve Dünya Kültürel Mirası, Detay Yayıncılık, 2. Bask1, Ankara.

Temurçin, K. (2014), Burdur Merkez İlçe'de Hizmet Faaliyetleri. Y. Atayeter ve K. Temurçin (Editörler), Burdur İli Merkez İlçesi’nin Coğrafi Etüdü, (1. Baskı). (s. 13-41). Burdur: Burdur Belediyesi Kültür Yayınları - 15.

Temurçin, K., Yolcu, A. ve K1lıç, M. (2018), Sürdürülebilir kalkınma düşüncesinde ihmal edilen "yer”: Türkiye'de bölgesel eşitsizlik ve çözüm mekanizması olarak kalkınma ajansları. F. Arslan, A. Karadağ, P. Aksak (Editörler), Sürdürülebilir Kalkınma ve Türkiye kitabı içinde (s. 467- 493). Ankara: Gazi Kitabevi.

Tatoğlu, E., Erdal, F., Özgür, H. ve Azakl1, S. (2002). "Resident Attitudes toward Tourism Impacts: The Case of Kusadasi in Turkey", International Journal of Hospitality and Tourism Administration, $3(3), 79-100$.

Uçar, M., Çeken, H. ve Ökten, Ş. (2010). Kırsal Turizm ve Kırsal Kalkınma (Fethiye Örneği). Ankara: Detay Yayıncilik.

Uçar, M., Uçar, H., Kurnaz, A. ve Akyurt Kurnaz, H. (2012). Kırsal Turizmin Sosyo-Ekonomik Yapıya Etkisi ve Fethiye Örneği, KMÜ Sosyal ve Ekonomik Araştırmalar Dergisi 14 (22): 75-82.

Ukav, İ. (2014). Adıyaman İlinde Kırsal Turizm Potansiyeli ve Geliştirme Fırsatları, Elektronik Sosyal Bilimler Dergisi, 3 (51), 15-33.

Uygur., M., S. ve Baykan, E. (2007). Kültür Turizmi ve Turizmin Kültürel Varlıklar Üzerindeki Etkileri, Gazi Üniversitesi Ticaret ve Turizm Eğitim Fakültesi Dergisi, (2). 
http://www.yesilova.gov.tr/ilcemiz-tarihcesi (Erişim Tarihi: 22.05.2019)

http://www.burdurkulturturizm.gov.tr/TR-155043/yesilova.html (Erişim Tarihi: 22.05.2019)

https://www.e-unwto.org/doi/book/10.18111/9789284414024 (Erişim Tarihi: 22.05.2019) 